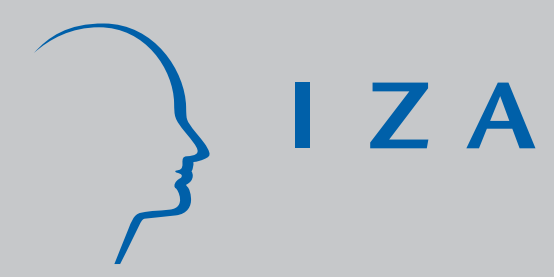

IZA DP No. 2691

Inequality and Union Membership: The Impact of

Relative Earnings Position and Inequality Attitudes

Daniele Checchi

J elle Visser

Herman G. van de Werfhorst

March 2007 


\title{
Inequality and Union Membership: The Impact of Relative Earnings Position and Inequality Attitudes
}

\author{
Daniele Checchi \\ University of Milan and IZA \\ Jelle Visser \\ AIAS and ASSR, University of Amsterdam \\ Herman G. van de Werfhorst \\ AIAS and ASSR, University of Amsterdam
}

Discussion Paper No. 2691

March 2007

IZA

P.O. Box 7240

53072 Bonn

Germany

Phone: +49-228-3894-0

Fax: +49-228-3894-180

E-mail: iza@iza.org

Any opinions expressed here are those of the author(s) and not those of the institute. Research disseminated by IZA may include views on policy, but the institute itself takes no institutional policy positions.

The Institute for the Study of Labor (IZA) in Bonn is a local and virtual international research center and a place of communication between science, politics and business. IZA is an independent nonprofit company supported by Deutsche Post World Net. The center is associated with the University of Bonn and offers a stimulating research environment through its research networks, research support, and visitors and doctoral programs. IZA engages in (i) original and internationally competitive research in all fields of labor economics, (ii) development of policy concepts, and (iii) dissemination of research results and concepts to the interested public.

IZA Discussion Papers often represent preliminary work and are circulated to encourage discussion. Citation of such a paper should account for its provisional character. A revised version may be available directly from the author. 


\section{ABSTRACT \\ Inequality and Union Membership: The Impact of Relative Earnings Position and Inequality Attitudes*}

In this paper we examine the connection between union membership and economic inequality. Using several surveys from the International Social Survey Programme (ISSP) covering the period 1985-2002, we initially examine the impact of relative earnings position on union membership and show that union membership is concentrated in the intermediate earnings groups. Next, we examine the impact of inequality attitudes on union membership. We show that union membership is not only affected by individual expected benefits related to education or earnings, but that attitudes towards inequality also play an important role. When controlling for attitudes, however, the relative income position remains significant in affecting the probability of union membership. We also show that there are no significant trends in the relationship between relative income positions and union membership. Our results indicate that union decline is observed in face of increasing earning dispersion, by attracting fewer members at both tails of earnings distribution.

JEL Classification: J51

Keywords: union membership, inequality attitudes

Corresponding author:

Daniele Checchi

Faculty of Political Science

University of Milan

Via Conservatorio 7

I-20122 Milano

Italy

E-mail: daniele.checchi@unimi.it

\footnotetext{
* The authors are listed alphabetically, and each has equally contributed to the paper. The authors thank Massimiliano Bratti and Antonio Filippin for helpful discussions in the initial phase of the project and for collaboration in exploring the data.
} 


\section{INTRODUCTION}

Trade union membership, in absolute numbers and relative to the size of the labour force, is in decline in many countries (OECD, 2004; Visser, 2006). However, it is not fully known what caused this decline. Cross-national empirical studies of trends in union membership and union density have often analysed aggregate statistics (Checchi and Visser, 2005; Western, 1997), which necessarily limits the scope of explored individual attributes that affect union membership.

In this paper we propose two groups of individual determinants that have not received the attention they deserve and analyse their predictive power of union membership using repeated cross-sectional data from seven countries. First, we will analyse the impact of individual relative earnings positions on union membership. There are reasons to expect that unions are predominantly catering to the interests of intermediate earnings groups and that low-earners and high-earners have, for different reasons, less incentives of joining a trade union. Assuming that workers join unions partly for self-interested reasons, the attractiveness of trade unions for particular groups of workers can be seen as a function of the degree to which unions are seen as effectively serving the material (wage) interests of that group. If unions for reasons of ideology, internal politics or organizational selfpreservation favour wage-compressing policies, they become less attractive for higher earning workers. If they must compromise their policies in order to keep higher-earning members satisfied, they may loose out among the lower-earning groups. If for reasons that are unrelated to union policy but determined by technological change or globalisation, trade unions have become less effective in redistributing earnings towards the median and upholding minimum real earnings (DiNardo, Fortin and Lemieux, 1996; Pontusson, Rueda and Way, 2002), they become less attractive as a venue for collective action of lower-paid workers. Our key hypothesis is that both these processes have happened as a result of skillbiased (rather than skill-replacing) technological and organizational change, making workers with higher skills and earnings less dependent on union organization and at the same time rendering unions less effective as organizations protecting workers at the lower end of the labour market.

Given that earnings inequality has risen in the past decades in many countries (Alderson and Nielsen, 2002; EC, 2005; Gottschalk and Joyce, 1998; OECD, 1996; Rueda and Pontusson, 2000), union membership decline may partially be caused by the compositional change in the earnings distribution. Simply put: if the tails of the earnings distribution have grown in size, this may have contributed to a decline in union 
membership. ${ }^{1}$ Moreover, if it is the case that lower- and higher- earning workers are decreasingly attracted to union membership across time, the compositional change in the earnings distribution is of even greater relevance.

It should be noted that the existing literature that connects earnings inequality with union density rates usually starts from the opposite end. The usual argument is that the decline in union membership and/or bargaining coverage is among the institutional factors causing greater inequality (Alderson and Nielsen, 2002; DiNardo, Fortin and Lemieux, 1996; Freeman, 1980; Rueda and Pontusson, 2000; Wallerstein, 1999). We do not reject this argument, but will provide reasons as well as empirical evidence supporting the reverse link, where changing inequality affects union membership rates through changes in the incentives to join.

A second group of individual attributes that we expect to be relevant for joining trade unions are people's attitudes towards social inequality. Joining a union can be seen as a personal endorsement of a form of collective action that, on the aggregate level, helps to reduce (earnings) inequality. Unions are 'vested interests' but also 'swords of justice', to use Alan Flanders' words (Flanders, 1970: 15). Reducing the inequalities in the labour market between blue- and white-collar workers, between women and men, or between black and white workers, is one manifestation of this aspect of unionism (Metcalf, 2005). This could imply that, apart from their own expected benefit from union action, individuals who share the opinion that inequality should be lower than is actually the case are more inclined to join a union than individuals who disagree with this opinion. Arguably, higher-earning people are more tolerant of inequality than those earning less and they are more likely to defend inequality as reward for effort or talent. Part of the explanation for a differential effect of relative earnings on the likelihood to join a trade union may therefore be found in different attitudes towards inequality.

The two types of explanations are not mutually exclusive but intertwined. It has been argued that norms and ideologies favouring more equality are attracting a decreasing part of the population in line with the progress of the neo-liberal ideologies proclaiming the sanctity of the market, the merits of achievement orientation and the rise of the 'Winner-Take-AllSociety' (see Frank and Cook, 1995). To the extent that this is the case, such changes in the distribution of values and attitudes could decrease the propensity of union membership independent of changes in actual earnings distributions (see Black, 2001, for cross-national

\footnotetext{
${ }^{1}$ For instance, Acemoglu (2002: 47) shows that in the decade from 1983 to 1993 in the US the employment share in the top and bottom 25-percent job categories rose from 35 to 38 per cent.
} 
evidence relating union membership to values). Besides the substantive interest in the impact of attitudes on the probability of union membership, it is also relevant to control for attitudes in order to strengthen empirical support for our preferred explanation of lower and possibly falling membership rates of workers with low and high earnings.

The paper proceeds as follows. In the next section we first discuss the literature relating union politics to the compression of wages and the problems that unions face in this regard. Next, we focus on the impact of attitudinal factors on union membership and formulate our hypotheses regarding this relation. In section 3 we describe our data set, derived from International Social Survey Programme (ISSP), and set out our empirical strategy. In section 4 we present and discuss our results. The paper ends with conclusions and a discussion of the findings.

\section{TRADE UNIONS AND INEQUALITY}

Figures 1 and 2 present evidence on the relationship between earnings/income inequality and union density. In figure 1 we present aggregate evidence covering the period 1960-1995 for a group of countries where information on income inequality was available over a consistent number of years. For some countries (notably United Kingdom and United States - one could also add Norway and Sweden) there is a clear negative correlation between these two variables. For most of the countries, income inequality has fluctuated without any recognisable trend (Deininger and Squire 1996), while over the full period between 1960 and 1995 union density has increased in some countries and decreased in others. In figure 2 we have extracted from our dataset (based on the International Social Survey Programme - see below) comparable measures of inequality and density over the period 1985-2002 computed on individual data. In this case the evidence at micro-level suggests a clear negative correlation between earnings/income inequality and union density (with the possible exception of Italy and the Netherlands).

[Figures 1 and 2 about here]

\section{The impact of unions on earnings inequality}

There are different reasons why trade unions should compress the wage distribution relative to the productivity distribution (see Freeman and Medoff, 1984). The literature 
connecting the two phenomena of earnings inequality and union density focuses largely on the causal direction running from union organization or union policy to wage or earnings (re)distribution. The general argument is that unions compress wages among union members and lower the differential between blue-collar and white-collar worker. Even though this may come with a 'mark up' for union members compared to non-members, thus increasing inequality for otherwise equal workers, the empirical finding is that the wage compressing effect is larger than the inequality increasing effect (Freeman, 1980; Freeman and Medoff, 1984; Card, 1998; 2001; Card, Lemieux and Riddell, 2004; Metcalf et al. 2001).

At the theoretical level, there are various reasons why and how unions compress the wages of their members. Or, if they negotiate agreements for all or most employees like they do in most continental European countries (EC, 2004; OECD, 2004), why they do so for most workers irrespective of union membership. Firstly, the aspirations and motives of union leaders and their members may be nested in a 'moral economy' and norms of fairness and equality may have a strong hold on them. Svenson (1989) has shown how such norms have informed post-war union wage policies of Swedish and German trade unions, albeit within the sobering realities of coalitional union politics and economic necessity. Secondly, trade unions may conduct a wage compressing strategy as part of a growth- and productivityenhancing strategy, seeking to squeeze low-paid work in inefficient firms or sectors out of the market (Agell and Lommerud, 1993; Horn and Wolinsky, 1988; Streeck, 1992). Unions may also try to redistribute income as an alternative to progressive taxation (Agell, 1999), though in both cases adverse effects on employment temper these egalitarian union policies. In Sweden, the development of an active labour market policy was intended to address these adverse effects, helping workers to upgrade skills and jobs, and shortening the time spent in unemployment. Active labour market policies are costly, however, and require political backing for high levels of taxation (Calmfors et al., 2001; Martin 2000). Thirdly, internal union politics may favour wage policies tending to the vote of the median union member. Since most modern unions organise heterogeneous workers with different skill and pay levels in the same sector or company, there must be a political mechanism for aggregating the potential diverse preferences of union members and make collective decisions. For instance, when deciding on annual wage increases lower paid members are better off with absolute rather than percentage increases. Under the medium voter model and given a mean wage higher than the medium, as is typically the case in earnings distributions, union policies will tend towards wage compression (Freeman and Medoff, 1984). As this would drive the higher-earnings groups with the strongest bargaining clout away, union are usually 
forced to compromise and introduce compensating benefits for their higher-earning members (Acemoglu and Pischke, 1999). Another reason why egalitarian union policies will be mitigated is that in many countries, for instance in Germany, the Netherlands, Sweden and Norway, strike decisions typically require supermajorities of 75 per cent or more; British law in the 1980s has also moved in that direction (Ebbinghaus and Visser, 2000; see also Mosher, 2002). These constraints will be lessened if union and collective bargaining structures are encompassing and high-skilled workers cannot 'exit'. Collective bargaining in Sweden during the 1960s and 1970s would seem a good illustration of this, though in 1983 the unions representing high-skilled worker in engineering managed to 'exit' via a crossclass coalition with employers in export industries who wanted more flexibility in wagesetting even at the price of paying higher wages (Pontusson and Svensson, 1996).

Where there is a sharp distinction between the union and non-union sector of employment, there is evidence that the earnings structure is flatter in the union sector (for the US: Card, 1996, 2001; DiNardo, Fortin and Lemieux, , 1996; Freeman and Medoff, 1984; for Canada: Card, Kramarz and Lemieux, 1999; DiNardo, Fortin and Lemieux, 1996; for the UK: Card, Lemieux and Riddell 2003; ; Metcalf, et al, 2001). In continental European countries this comparison is much harder to make, since collective agreements negotiated by the trade unions are often extended to non-unionised firms and generally applied to nonunion members. On average, 70 percent of all employees in continental Western Europe are covered by collective agreement, compared with 14 percent in the US, 32 percent in Canada and 35 percent in the UK (EC, 2004; Visser, 2006). Where it is possible to compare earnings of workers covered by collective agreements with similar workers who are not covered, the 'agreement mark-up' tends to be two-to three times smaller in Sweden, Norway, Italy, Germany and the Netherlands compared to the UK, and four times compared to the US (Aidt and Zannatos, 2002; Blanchflower, 1996; Teulings and Hartog, 1998). However, these comparisons are rather crude and do not control for union-status selectivity, i.e. the possibility that higher-earning individuals may decide to work in non-union occupations and firms in the expectation of earning higher wages (Aidt and Zannatos, 2002: 41).

If nearly everybody is covered by union contracts or if the same mechanism for adjusting wage rates applies to all workers independent of union status (as was the case under the 'scala mobile' in Italy before 1992 or with wage indexation in the Netherlands before 1983), we cannot infer the effect of unions or union-based institutions from a comparison of union and non-union wages. There are two alternative methods, of which the second is probably the more effective one (see Freeman, 2005). We can compare earnings 
distributions across countries with different levels of collective bargaining and union coverage. Such comparisons invariably show that countries with the highest coverage have the lowest wage dispersion. Other measures, reinforcing this association, relate to union structure (unions encompassing low and high earning groups) and bargaining centralisation (Blau and Kahn, 1996; Iversen, 1999; OECD, 1996; 2004; Visser, 1990; Wallerstein, 1999).

The second method tries to test whether changes in unionisation and wage-setting institutions are associated with changes in wage dispersion. Empirical research with British household data (Bell and Pitt,1998; Gosling and Machin, 1995), for instance, demonstrated a relationship between union decline and the widening of the earnings distribution. Metcalf et al. (2001) report that UK unions narrow the pay differentials between women and men, blacks and whites, manual and non-manual workers, and between people with and without health problems. The authors show also that the equalizing effect of union presence was much smaller than it had been in an earlier and comparable study with data for 1978, when British unions registered perhaps their maximum post-war influence (Metcalf,1982). Twothirds of the union effect on wage dispersion had disappeared in the late 1990s (Metcalf et al. 2001: 69). Hibbs and Locking (1996) and Iversen (1999) show that pay differentials in Sweden started to rise after the move from nationwide to industry bargaining in 1983 . The observed trends in earnings inequality, shown by the data from the structure of earnings database of Eurostat (EC, 2005: 165), support the hypothesis that trend reversals are related to changes in wage-setting institutions. Thus, downward trends in wage inequality ended in the 1970s in the UK, in 1983 in Sweden (when the coalition for a nation-wide 'solidaristic' wage policy was broken), 1990 in Denmark (decentralisation of key agreements), 1993 in the Netherlands (the "New Course" Agreement, with strong decentralising effects) and 1996 in Germany (following the progress of opening clauses in sectoral agreements). Of course, these associations in timing do not constitute definite proof and should be checked against other influences. However, the data do support the idea that wage dispersion is lowest in countries with nation-wide bargaining and high union coverage, and also that across time less centralised wage setting is associated with wider inequality.

These findings point to the declining capability of trade unions to stem the rise in earnings inequality. Generally, the rise in earnings inequality across the western world has been related to skill-biased rather than skill-replacing technological growth, with returns to education sharply rising during the 1980s and 1990s, whereas average real wages for lowskilled workers have stagnated or fallen in this period (Acemoglu, 2002; see also Alderson and Nielsen, 2002). This development has affected the behaviour of firms and promoted a 
change in work organization and wage-setting behaviour, which has profoundly changed the governance and size of the (internal) labour markets that were the bedrocks for union organisation. More intensive competition on a worldwide scale has made firms acutely aware of costs and productivity. The solution many employers have reached is to reorganise work around decentralised management of human resources, customised products and working schedules, and reorganise tasks in such ways that they can be partitioned in modules. This makes it easier to subcontract tasks, employ part-time workers and hire temporary staff for some tasks, while core works is multi-tasked and carried out in teams. Employment security and pay are being defined less in terms of the seniority and job status than in terms of the knowledge, competences and effort workers bring to the jobs and develop while working. More industrial relations activities have gravitated towards the level of the firm (Katz and Darbishire, 2000; Marginson and Sisson, 2004).

Fixing the standard pay rate for the job across firms in the industry was the "common rule' and most heralded union wage policy of the first decades after 1945, even in the United States (Flanders, 1970; Reynolds, 1951; Slichter, 1950). Objective pay criteria, based on job descriptions and seniority, diminish the power of supervisors and the possibilities of discrimination and favouritism. Unions typically pressed for the standardization of employment contracts in order to protect workers against uncertainty, simplify collective regulation, de-couple the economic situation of workers from that of their employing organization, and suspend as much as possible competition between workers, so as to enable them to act in solidarity (Streeck, 2005). Standardization involved explicit and agreed definitions of 'normal' effort, 'normal' hours and 'normal' pay, guaranteeing employers reliable performance of predictable routine tasks at an average level of effort, thus allowing the union to act as the guardian of the wage-effort bargain. This institutional solution of the mid-twentieth century is now deeply challenged.

Breaking away from centralised (industry) agreements gives firms more scope for merit- and performance based pay (Lindbeck and Snower, 2001). In the UK, there is evidence that performance related and merit pay is associated with the derecognition or the absence of unions (Heery, 2000). According to Brown et al. (1998), in the UK "for many firms, the advantage of breaking away from an existing structure of collective bargaining was to increase the dispersion of pay, both within grades and between hierarchical levels" and "there was a greater tendency towards linking pay rises to individual performance in derecognising firms than in those retaining collective bargaining. Employers tended to gain substantial discretion to set individual pay by open-ended appraisal procedures." One way of 
doing this is by making job descriptions vaguer. Across Europe, there is some evidence that variable and performance related pay has become more wide-spread in recent times among both non-manual and manual employees, although only for a relatively small proportion of total weekly or monthly pay (EC, 2004; 2005).

\section{The impact of earnings position on union membership}

We expect that unions are predominantly attractive for intermediate earnings groups, whereas low-earners and high-earners have, for different reasons, less incentives of joining a trade union. Highly skilled workers may believe that they do better by staying outside the union, especially when unions engage in wage compressing policies. In addition, they may have sufficient bargaining power as individuals. Moreover, if it is true that risk adversity decreases with income (e.g. Hartog et al. 2002), and if risk adversity is correlated with the tendency of buying insurances (Barsky et al, 1997), then higher-earning workers should be less persuaded by the insurance function of trade unions which is based on risk-pooling (Agell, 1999; see also Agell and Lommerud, 1992, and Burda, 1995). In contrast, low skilled and lower earning workers should be more attracted by the type of insurance and protection that unions promise. However, workers whose earnings and working conditions would benefit most from collective action tend to be least able to get it (Crouch, 1982). Lower-paid workers may be concentrated in sectors and firms that are most difficult to organize, and they may have more frequent spells of unemployment or inactivity, making it more difficult to retain membership ties Elias, 1996; Klandermans and Visser, 1995; Visser, 2002). Moreover, if trade unions have become less effective in reducing earnings differentials and, in particular defending the real earnings of the low-skilled (see DiNardo, Fortin and Lemieux, 1996; Metcalf, 2005; Pontusson, Rueda, and Way, 2002), lower-paid workers may not bother to join unions or discontinue membership for reasons of disillusionment (see Baccaro \& Locke 1998). Finally, Acemoglu, Aghion and Violante (2001) suggest that skillbiased technological change has weakened the coalition supporting the (mandatory or negotiated) minimum wage and thus indirectly contributed to de-unionisation, especially of workers with lower earners. ${ }^{2}$ Together, these propositions support the recent contention of

\footnotetext{
${ }^{2}$ If wage compression favours firm-sponsored training by firms (because they are already paying unskilled workers a wage above their marginal productivity - though the empirical evidence is not always consistent: see Bassanini et al. 2006), and if skill-bias technological change makes the compression untenable (because skilled workers prefer individual negotiation), then the firms stop training unskilled workers, and find it more convenient to get rid of them. Because of the skill-biased technological change, an unskilled worker
} 
Streeck (2005: 278) that in today's labour markets "the numbers are rising of those who have enough market power to do without collective organization, as well as of those who have too little market power to be capable of it." Today's trade unions would seem to be squeezed into a narrowing middle range of the earnings distribution.

\section{Attitudinal factors and union membership}

All previous explanations are based on the logic of strict economic calculus with (prospective) members weighing their material (wage) interests and evaluating the union in terms of how well they serve those interests. However, it is unlikely that union membership is only caused by rational motivations, partly because of the fact that in the European countries that we study members and non-members equally benefit from the employment contracts (e.g. wages and terms of employment) that are negotiated by unions. Such an 'open-shop' system makes the study of union membership partly a 'collective good' problem (Crouch, 1982; Booth 1984). An important source for contributions to collective goods comes from the normative elements guiding such contributions (Hechter, 1987). Peer group pressure towards the sanctioning of 'free riders' is probably another important source for 'open shop' union organizing (Booth, 1985; Naylor, 1990). Such norms may, at the personal level, be based on values or attitudes towards inequality. Group-based social customs tend to be stronger where values of fairness and equal pay for equal work are upheld (Fehr and Gächter, 2002). Given the egalitarian agenda of unions, it is therefore likely that attitudes towards inequality affect the individual decision to join the union and retain membership. For example, in a representative survey of attitudes and patterns of joining in the Netherlands in 1992/3, it turned out that union activity was highly valued because of its association with fairness and equality (Klandermans and Visser, 1995).

This is why we are interested in exploring the role of individual egalitarian attitudes in shaping the incentives to joining unions, in addition to the relative income position of these individuals. We have three reasons to include inequality attitudes in our study of trends in union membership. First, we are substantively interested in the effects of inequality attitudes on union membership. Second, by including attitudes in our models, we can examine to what extent well-known variations in membership across subgroups, for example regarding levels of education or skill, gender or supervisory status, can be explained by

experiences a reduction in her relative wage, a reduction in training opportunities and an increase in unemployment risk. The joint combination of these three developments makes union membership less and less likely, despite the fact that unions may not be directly responsible for these changes 
differences in inequality attitudes. Third, attitudes serve as a control variable for our main explanation of membership decline related to relative earnings position, as discussed above. Because our key hypothesis is derived from assumptions about rational decision-making about union membership based on material (wage) interests, we need to control for attitudinal factors to ensure that variations in the propensity to join across earnings positions are not in fact affected by normative standpoints rather than rational calculation. This is all the more important in view of research showing that attitudes towards inequality are correlated with financial resources (Svallfors, 1993; 1997).

Attitudes towards inequality can be subdivided in at least three types, each of which will be empirically related to union membership in our analysis below. The first is the most general and simply comprises the affirmation that 'inequality in society is too large'. We will call this the general inequality attitude. The second type is more specific and endorses the opinion that earnings should be redistributed. One may assume that individuals, while evaluating the level of inequality in a particular society, have specific ideas about the actual and legitimate earnings of specific occupations. Relating the estimates of respondents of what they believe are acceptable or legitimate earnings, we can construct a more specific preference for more or less egalitarian outcomes. Such specific inequality attitudes have been used by Jasso (1999) to construct a social justice index with the ISSP data.

Svallfors (1993), using ISSP data like we do, has used such attitudes to compare inequality attitudes in Sweden and Britain. He reports that in Sweden attitudes about the range of legitimate earnings are strongly related to social class whereas they hardly are in Britain, where the accepted range of what people believe to be acceptable earnings is much wider for all classes. ${ }^{3}$ Recently, Osberg and Smeeding (2006) have constructed an empirical measure of inequality attitudes based on respondents' evaluations of actual and legitimate pay for a range of occupations. Based on their responses to ISSP survey questions on actual and perceived pay for a range of occupations, it is possible to assign a particular preference for redistribution to individual respondents. Their measure has the advantage that not only legitimate earnings are observed, as is the case in Svallfors (1997), but also the perceived actual earnings. By inspecting both, a preference for redistribution - or its reverse: the tolerance for inequality - can be calculated which takes account of the perceived degree of

\footnotetext{
${ }^{3}$ In another cross-national study, Svallfors (1997) has related the attitudes about the range of legitimate earnings to different types of welfare states. He found that the difference in legitimate earnings between an unskilled factory worker and a chairman of a national company was a factor 2.3 in Scandinavian welfare states, going up to a factor 11 in the USA.
} 
redistribution that has already been achieved. We adopt their approach and will relate one of their empirical measures of 'inequality tolerance' attitudes to union membership.

The third type of attitude that may motivate people to join a trade union is more specifically concerned with the perceived need for collective action in order to compress earnings inequality, for instance defending wage coordination or some kind of levelling and protection of low-paid workers. If egalitarian attitudes motivate people to join the unions, this may come together with a conviction that collective action is necessary to achieve greater equality. We call this the 'inequality needs collective action' attitude. It is measured by asking people whether they agree with the statement that "Inequality continues to exist because ordinary people don't join together to get rid of it".

With regard to the relative importance of these three types of attitudes there are two different scenarios. First, it might be argued that more specific attitudes have a stronger effect than general inequality attitudes, the latter being 'vague', less contextualised and less committing. Research on intentions has shown that the more these can be put in concrete terms, the stronger their predictive power for subsequent behaviour (Ajzen and Fishbein, 1980). This would imply that the 'inequality needs collective action' attitude should have a larger effect than the others and that the 'general inequality attitude' has the weakest effect. However, people may think about other forms of collective action, for instance political action or criticise the unions for being ineffective when they score high on the inequality needs collective action' attitude. In that case, a more general attitude toward inequality should have a stronger effect on membership than the more specific attitude on collective action. Given this uncertainty, we will use all three indicators and see what works best.

\section{DATA AND OPERATIONALIZATION}

\section{Data}

We make use of the cross-national surveys of the International Social Survey Programme of various years. For the general study of the impact of earnings and other relevant objective characteristics on union membership we analyse the ISSP data from 1985 to 2002 for seven countries: Western Germany, Eastern Germany, Sweden, Norway, Italy, 
Netherlands, Britain. ${ }^{4}$ We have selected these countries among all available ones according to two criteria. On the one hand, we have considered the presence in more than one survey, in order to investigate potential variations along the time dimension. On the other hand, we only consider countries characterised by an 'open-shop' union system. In an 'open-shop' framework, a single worker may observe the aggregate inequality measure as a proxy of the egalitarian attitude and effectiveness of unions, whereas in a 'closed-shop' context local inequality measures become crucial. Since ISSP surveys do not report information on inequality at the local or establishment level, we were forced to leave the United States out of our sample. The remaining sample of seven countries gives a nice spread of different welfare state and industrial relations types - from liberal market economies to more coordinated ones, and from universalistic (Nordic) welfare states to more conservative (Germany, Netherlands), liberal (UK), and family-oriented (Italy) ones, all of this potentially reflecting in inequality distributions and attitudes about inequality (Svallfors, 1997). Within each country/year sample we have only included wage and salary earners in employment in our analysis, excluding the unemployed, the self-employed and those outside the labour force. $^{5}$

Our overall sample consists of 55.109 individuals, unevenly distributed across countries: West Germany (1985-2002, 18 surveys, 12.094 observations), East Germany (1991-2002, 12 surveys, 4.094 observations), Sweden (1994-2002, 8 surveys, 5.194 observations), Norway (1989-2002, 14 surveys, 11.615 observations), Italy (1985-1998, 12 surveys, 4.628 observations), Netherlands (1987-2002, 11 surveys, 7.901 observations) and Great Britain (1985-2002, 18 surveys, 9.583 observations). The union density rates computed from ISSP samples are rather consistent with aggregate evidence, as can be assessed looking at figure 3. If we exclude one survey (Britain in 1989), the ISSP data are almost in line with other evidence obtained at macro level (Ebbinghaus and Visser, 2000).

[Figure 3 about here]

\footnotetext{
${ }^{4}$ We have decided to keep the treat Eastern and Western Germany as two separate cases, although these are politically unified since 1990 and the same industrial relations institutions apply, producing a number of convergent trends (Schnabel and Wagner, 2003). However, with regard to concerns about actual and legitimate inequality we expect differences as part of the legacy of communist labour relations (see Blanchflower and Freeman, 1997).

5 More precisely, we have followed three criteria in selecting the sample: formal employment (excluding individuals working in the family, the unemployed, students and retired workers); working for government or private enterprises (excluding charity, volunteers, NGO); excluding the self-employed (there are few individuals who declare to be both "self-employed" and "working for government" or "working for private enterprises", but we have left them out of our analysis).
} 
The attitudes to inequality are part of the ISSP surveys of 1987, 1992, and 1999. Not all three years are available for all countries. Trends across three survey years can be analysed for West Germany and Britain. For Norway and East Germany two years are available (1992 and 1999). For three countries only one survey year is available: the Netherlands (1987), Italy (1992) and Sweden (1999).

\section{Earnings position}

We describe the relative earnings position of each individual by the relative distance from the survey median income (computed within each country/year sample). Positions above or below the median are kept distinct in order to distinguish different attitudes of people at both tails of the earnings distribution. If we define $y_{i c t}$ as the earnings of individual $i$ in country $c$ and survey year $t$, and $\hat{y}_{c t}$ as the median earnings for the same country/year, our measures are given by

$$
\begin{array}{ll}
R_{i c t}^{a b o v e}=\frac{y_{i c t}-\hat{y}_{c t}}{\bar{y}_{c t}} ; \quad R_{i c t}^{\text {below }}=0 & \text { if } y_{i c t}>\hat{y}_{c t} \\
R_{i c t}^{\text {above }}=0 ; \quad R_{i c t}^{\text {below }}=\frac{\hat{y}_{c t}-y_{i c t}}{\bar{y}_{c t}} & \text { if } y_{i c t}<\hat{y}_{c t}
\end{array}
$$

A higher score indicates a larger distance between individual earnings and the median earnings in the country/year under study. When individual earnings information is missing, but family income information is available, we compute the relative income position from the latter variable and use it instead of the former. ${ }^{6}$

\section{Attitudes towards inequality}

We look at three different types of attitudes towards inequality. The 'general inequality' attitude is based on the survey item 'Earnings inequality in my country is much too high'. A higher value indicates agreement with this item. The 'inequality tolerance' attitude is based on work by Osberg and Smeeding (2006). For five occupations (doctor,

\footnotetext{
${ }^{6}$ We have controlled for potential distortions introduced by this solution by creating a dummy variable which is one when the replacement takes place, and by inserting its interaction with the relative income position in the regressions, without finding statistical significance except two cases (Netherlands-below median and Britainabove median). Available from the authors.
} 
chair of a large company, skilled worker, unskilled worker, and minister) individual respondents estimate the actual earnings that they believe these occupations pay as well as the earnings that these occupations in their opinion should pay Next, for each respondent an OLS regression coefficient is computed (on $\mathrm{N}=5$ occupations) regressing the should-earn answer (representing the dependent variable $Y$ ) onto the do-earn answer (as our predictor $X)$. A lower slope coefficient indicates a desire for redistribution and, symmetrically, a higher coefficient expresses a demand for less redistribution or greater tolerance of inequality. Using the standard equation for OLS regression slopes, this individual measure for individual $i$ is given by

$$
\beta_{i}=\frac{\sum_{k=1}^{5}\left(Y_{k}-\bar{Y}\right)\left(X_{k}-\bar{X}\right)}{\sum_{k=1}^{5}\left(X_{k}-\bar{X}\right)^{2}}
$$

Finally, the 'inequality needs collective action' attitude is based on the survey item 'Inequality continues to exist because ordinary people don't join together to get rid of it'. A high score indicates agreement with this item.

For all three types of attitude we took the z-value within each country-year combination. The correlation between the 'general inequality' and the 'inequality tolerance' attitude is -0.309 ; between 'inequality tolerance' and the 'inequality needs collective action' attitude -0.105 ; and between the 'general inequality' and the 'inequality needs collective action' attitude 0.271 .

[Figure 4 about here]

Figure 4 shows the trends in these inequality attitudes in the countries under analysis. The first graph shows that, particularly in the 1990s, there has been a increasing tolerance of inequality (i.e., a higher regression slope of the Osberg-Smeeding index). This trend is found in all three countries where we can compare different years : Norway, Western Germany and Britain. Furthermore, it is remarkable that the lowest preference for redistribution (i.e., the highest score on the Osberg-Smeeding redistribution slope) is found in Norway. This is in contrast with Svallfors' findings (1997), but it should be noted that his measure of the range of legitimate earnings did not include information on the perceived actual pay of 
occupations. So, although Svallfors' analysis showed that the Norwegian population would prefer a lower dispersion of earnings between different occupations than did respondents in Germany, Australia and the US, this does not translate in a stronger preference for redistribution if one takes into account the (perceived) actual pay of occupations in Norway. This is obviously only the case if the (perceived) actual earnings dispersion in Norway is smaller than elsewhere, as is according to our data indeed the case (see Figure 2). In the second graph we see that support for the statement that "earnings inequality is too high" is declining in the 1990s. The third graph shows that there is hardly any trend in the inequality needs collective action attitude.

\section{Additional controls}

In addition to relative earnings position and various measures of attitudes towards inequality, we do control for the usual demographics (gender, age, marital status), for education (measured in four categories: lower secondary or less; upper secondary; beyond secondary; completed college) and some job characteristics (working hours, public/private, supervising someone else). Descriptive statistics are reported in table A1 of the Appendix.

\section{RESULTS}

\section{Earnings position and union membership}

Our first analysis consists of an empirical estimation of the impact of various observable characteristics, including earnings position, on union membership in seven countries. This is done on all available surveys from 1985-2002 and not only the three survey years in which inequality attitudes were included. ${ }^{7}$ In table 1 we report the results of a probit model predicting union membership. The coefficients are marginal effects, indicating the difference in the probability if the independent variable undergoes a unitary change. We see that women are less likely to join a trade union than men. However, in the two Scandinavian countries this effect is smaller, if at all significant. In all countries, the young (defined as individuals younger than 30 ) are less likely to be union members than older

\footnotetext{
${ }^{7}$ In order to keep the maximum sample size, when missing values were encountered for some variable (typically the case of "supervising someone" and "uncompleted college"), we have replaced them with country averages. Results are unaffected by this change, but standard errors for other variables are smaller.
} 
workers. ${ }^{8}$ In all countries except Germany and the Netherlands, married persons are more likely to join the union than non-married workers. Supervisors are less likely to become a trade union member than subordinates, except in East Germany and the Netherlands. ${ }^{9}$ There is a very strong impact of public sector on union membership in all countries, but particularly so in Norway and Britain.

The impact of education varies across countries. The general pattern is that people with at most lower secondary level have the highest likelihood to join the union, while tertiary educated workers are less likely to become union members. West Germany is the only country where the probability reduces monotonically for each additional step on the educational distribution. ${ }^{10}$ There is also a rather large education effect in Sweden, although university graduates have a similar chance of membership as do persons with some postsecondary education. In Italy, Norway, the Netherlands and Britain, male university graduates have a lower probability of membership than people of lower secondary education, but the other educational categories are rather equal to the lower secondary group. University educated women, however, are much more often union members than their male counterparts, as can be seen from the positive interaction terms relative to the negative main effects of a university degree. This may be related to the larger proportion of highly educated women employed in unionised public service professions.

[Table 1 about here]

With regard to the impact of the variables indicating relative earnings positions, the data clearly support our hypothesis that the trade unions mainly attract workers from the intermediate earnings groups. The further one's personal income is from the median, the lower the likelihood of membership. This holds in all countries for both the distance above

\footnotetext{
${ }^{8}$ Similar gender and age effects are found by Blanchflower (1996), who was using a larger country sample drawn from ISSP 1985-93 (unlike us, he also retained the self-employed in his sample). These results are reconfirmed in Blanchflower 2006. There, he stresses the existence of an inverted U-shaped relationship between membership and age, with the highest membership rate in age groups between 40 and 50 .

${ }^{9}$ This is probably due to self-sorting based on unobservables: supervisors could be selected because they are against unions.

${ }^{10}$ Schnabel and Wagner (2005), using the European Social Survey conducted in 2002/03, find that more the educated worker are less likely to be union members only in Belgium and Denmark, but not in the other EU countries, including Germany. Blanchflower (1996) finds a negative impact of years of education, and a positive impact of the interaction between working in the public sector and years of schooling (probably capturing the presence of teachers and health workers).
} 
and the distance below the median. ${ }^{11}$ The one exception is Italy, where we did not find a significant impact of the distance above the median on union membership. In general, the negative impact on union membership of earnings below the median is much stronger than that of the earnings above the median. Thus, trade unions are less attractive to workers with low earnings, possibly because of disappointment in union egalitarianism, or a stronger tendency to free-riding and saving on the financial costs of union membership, which are relatively higher for low-paid workers. If we analyse each survey year separately, we do not find any systematic change in the effect of the earnings distance to the median (above or below) on union membership. This suggests that the observed decline in union membership may (partly) be caused by the changes in the earnings distributions, i.e. the contraction of the middle, but not by a general change in the associations between earnings positions and union membership. $^{12}$

In order to be more confident in the causality of earnings position affecting union membership, rather than the other way round, we resort to instrumental variable estimation of union membership probability. In this model the earnings position variables are considered as endogenous, and they are instrumented using educational attainment. The results of this analysis are reported in table A2 in the Appendix. These results show that the instrumented relative earnings measures retain significance in all countries for employees with earnings above the mean and in four for those with earnings below the mean, but not in the case of East Germany, Italy and Sweden. Their impact slightly increases relative to the coefficients obtained in table 1, suggesting a possible endogeneity in the coefficient estimation. It is interesting to note, like we did before, that being below the median has a much stronger negative effect on union membership than being above the mean. Overall the data provide support to the negative correlation between earnings position (proxied by relative distance from the median) and the probability of union membership.

\footnotetext{
11 This is in line with the findings of Addison, Bailey and Siebert (2003), who report that male density in the UK “..was lowest among the least skilled (lowest decile), highest at the third decile and then somewhat lower for the more skilled." However, union power, which they define as the union wage premium times the decile density rate, was highest for the less skilled workers. On the contrary, our result contrasts with Goerke and Pannenberg 2004, who analyse the GSOEP panel data for Germany and find that the (log)income position of workers is irrelevant for predicting union membership.

${ }^{12}$ These analyses are available from the authors upon request. See however the plots of the coefficients presented in figure 6 .
} 


\section{The impact of inequality attitudes on union membership}

As a first examination of differences in attitudes between union members and nonmembers, we calculated kernel density estimates of the permissiveness of inequality separately for union members and non-members. Figure 5 displays these estimates. We recall that a high score on the redistribution preference computed according to Osberg and Smeeding (2006) indicates a high tolerance for unequal pay. The figure shows that, in most countries, the solid lines (representing union members) are to the left of the dashed lines, which supports the notion that a preference toward redistribution may inspire people to join a labour union.

[Figure 5 about here]

The second way in which we examine the impact of attitudinal factors on union membership is by estimating a probit regression analysis on the pooled sample. The results of this analysis are reported in Table 2, showing four model specifications. Model 0 uses the same variables as in table 1 , but now with the fewer datasets that include the attitude items, and with a pooled analyses for all countries including country dummies. Model 1 adds the three attitude variables. Model 2 adds the multiplicative interactions between relative earnings positions and attitudes, and model 3 replaces these interactions with interactions between survey year and attitudes.

In model 0 we find support for most of the findings reported and analysed before when we used the full data set with all years. Most importantly for our purpose, people with income levels that are more distant to the median (either above or below) are less likely to be found in the unions. In model 1 we see that attitudinal factors have the expected effect on union membership. Firstly, people who tolerate greater inequality have a lower probability of membership. Secondly, people who find inequality too high in their society have a higher likelihood of union membership. This effect is more than twice as large as the effect of inequality tolerance. Finally, people who think that inequality exists because people do not join together - thus indicating an inclination to collective action - have a slightly higher chance of membership than people who disagree with this statement.

The next question is how attitudinal factors affect the impact of the other variables on union membership. Differences across time and across countries in membership rates cannot be explained by time or country variation in attitudes. The coefficients of model 1 are very similar to those of model 0 . The gender difference in membership cannot be explained by 
gender differences in inequality attitudes either. This is unsurprising, as women are generally more critical towards the existing earnings distribution than men (van de Werfhorst and de Graaf, 2004). Neither the effect of schooling, nor the difference between public and private sector workers can be explained by differentials in inequality attitudes. Thus, the impact of attitudinal factors is purely additive and offers us no further interpretation of some wellknown variations in union membership.

With regard to the impact of relative earnings position we see that the impact of the distance of one's earnings above the median is partly, but modestly, explained by differences in inequality attitudes. The coefficient of this variable decreases from -0.109 to -0.084 . Thus, only to a limited extent it is true that high-earners tend to distance themselves from the unions because of there greater tolerance of and lower concerns about inequality, as expressed in these attitudes. Most of the main effect remains, which supports the view that their non-membership is at least partially based on rational considerations informed by material interests rather than on expressly normative considerations.

Model 2 shows that there is no interaction between earnings position and inequality attitudes. Thus, the impact of inequality attitudes on union membership is independent of one's relative earnings position. In model 3 we see that the impact of the inequality tolerance attitude is only prevalent in 1987 (as seen in the main effect) and reduced to zero in 1992 and 1999. The impact of the general inequality attitude seems to have slightly increased between 1987 and 1999, with a positive albeit non-significant, interaction effect of 0.036 .

[Table 2 about here]

In table 3 we have replicated the analysis of table 2 by country. This analysis reveals that the impact of inequality tolerance on union membership is only prevalent in Britain. The impact of the general inequality attitude is much more widespread across Europe, although no significant effects on union membership were found in the Netherlands and East Germany. Model 2 in table 3 shows that there is no systematic variation between earnings groups in the impact of attitudes on union membership, which confirms the pooled analysis reported in table 2. Finally, in table 4 we show the trends in the impact of attitudes for each country. This table shows that the negative effect of the inequality tolerance attitude on the probability of union membership is mainly found in Britain in 1987, but that this effect decreases and approaches zero in later years. In contrast, the positive effect of the general 
inequality attitude on the probability of union membership gains in importance in Norway in 1999 relative 1992.

[Tables 3 and 4 about here]

\section{CONCLUSIONS}

In this paper we have examined the connection between union membership and one dimension of economic inequality, indicated by people's relative earnings. First, we examined the impact of the distance of individual earnings to the median on union membership and found that trade unions are most attractive for the intermediate earnings groups. One implication of this finding is that, if earnings inequality increases, union membership decreases as a result of the compositional change in the earnings distribution. However, we did not find support for the hypothesis that the association between relative earnings position and union membership itself had changed during the period under study. Our data, shown in figure 6, suggest trendless fluctuation. In other worlds, union membership decreases because the ground on which middle earnings stand is contracting, with the bottom falling and the top pulling away. Unions do not decline - or at least we cannot find confirmation for this from the admittedly incomplete data - because the lowerpaid are increasingly disillusioned or the higher-paid are increasingly doing fine without trade unions. What matters for union decline is that there are more of each of them and less in the middle.

Our second line of investigation was concerned with the impact of inequality attitudes on union membership. We did so for three reasons. Firstly, we showed that union membership is not only affected by individual expected benefits resulting from objective criteria such as education or earnings, but that attitudes towards inequality do play a role as well. People are partly motivated to join the trade unions because they feel that economic inequality in society is too large, earnings should be redistributed and some form of collective action is needed. Secondly, we have shown that well-known variations in union membership (e.g. by gender, skill level, or supervisory status, or sector of employment) are not explained by differences in attitudes across these subgroups. Thirdly, by controlling for people's attitudes, we can be more confident that the impact of the earnings distance to the median is not itself caused by differential attitudes, but is based on possibly rational consideration of mainly material interests. 
We can therefore go back to the literature on union membership decline with additional insights. In addition to the well-known compositional effects related to the changes in labour markets and the rise of a post-industrial society, we have highlighted the role of growing earnings inequality and of different inequality attitudes in explaining union membership decline. Workers have taken up union membership either because they hold egalitarian opinions and believe that unions are instrumental in achieving more inequality, or they are not excessively anxious about being hurt by egalitarian policies of unions, because they are not that far from the median earnings position that such policies seem to benefit most. People belonging to the top tail of the earnings distribution may rationally 'vote with their feet' by leaving union membership or they never joined the union in the first place. They may see the 'insurance' offer by the unions against unforeseen mishaps in the future as too costly for them or they may tolerate a higher risk for themselves together with a higher level of inequality around them. Conversely, lower paid workers may leave the unions, or never become member, when the union's policies to defend the bottom in the labour market and close the gap in relative earnings is perceived as ineffective.

Thus, any exogenously given increase in earnings inequality, be it as the consequence of skill-biased technological change, migration or 'globalisation', has negative implications for the unions. Should they give up their egalitarian policies in face of these changes, if such policies engenders disillusionment among the lower paid and provokes higher-earning groups with strong market power to leave? The answer has to be qualified. By abandoning policies aiming at wage compression through 'equal pay for equal work' policies based on job-classification and objective pay schemes ${ }^{13}$, seniority clauses and automatic indexation, a union might retain more members from the top part of the earnings distribution. But it is likely to loose support in the middle part of the distribution where most people still are. Finding ways to check growing earnings dispersion, especially at the lower end of the labour market, without alienating higher earning workers, still remains the best strategy for the unions, but one that has become very challenging.

\footnotetext{
${ }^{13}$ See proposition 1 in Metcalf et al. 2001: "In setting pay, workplaces where unions are recognised will make greater use of objective criteria such as job classification and seniority. Non-union workplaces will make greater use of subjective performance appraisal and core competencies than unionised workplaces. This implies, in turn, that where contingent pay is used unionised workplaces will have schemes based on objective criteria - share options or profits - whereas non-union workplaces are more likely to use merit-based schemes." (p.65)
} 


\section{References}

Acemoglu, Daron 2002. 'Technical Change, Inequality, and the Labor Market'. Journal of Economic Literature XL: 7-72.

Acemoglu, Daron, and Jochen-Steffen Pischke 1999. 'The Structure of Wages and Investment in General Training'. Journal of Political Economy 103: 539-572.

Acemoglu, Daron, Philippe Aghion and Gianluca Violante. 2001. 'Deunionization, Technical Change and Inequality'. Carnegie-Rochester Conference Series on Public Policy 55: 229-264.

Addison, John., Ruchard Bailey and Wolfgang Siebert. 2003. 'The impact of deunionization on earnings dispersion revisited'. IZA Discussion Paper n.724.

Agell, Jonas 1999. 'On the Benefits from Rigid Labour Markets: Norms, market failures, and social insurance'. Economic Journal 109: 143-164.

Agell, Jonas, and Kjell Erik Lommerud 1992. 'Union Egalitarianism as Income Insurance'. Economica 59: 295-310.

Agell, Jonas, and Kjell Erik Lommerud 1993. 'Egalitarianism and Growth'. Scandinavian Journal of Economics 95: 559-579.

Aidt, Toke, and Zafiris Tzannatos 2002. Union and Collective Bargaining, Economic Effects in a Global Environment. Washington, DC.: The World Bank.

Ajzen, Icek, and Martin Fishbein 1980. Understanding Attitudes and Predicting Behavior. Englewood Cliffs, NJ.: Prentice Hall.

Alderson, Arthur S., and François Nielsen 2002. 'Globalization and the Great U-Turn: Income Inequality Trends in 16 OECD Countries.American'. American Journal of Sociology. 107: 1244-1299.

Baccaro, Lucio, and Richard M. Locke 1998. 'The End of Solidarity? The decline of egalitarian wage policies in Italy and Sweden'. European Journal of Industrial Relations 4: 283-308.

Barsky, Robert B., F.Thomas Juster, Miles S. Kimball and Matthew D. Shapiro 1997. 'Preference Parameters and Behavioral Heterogeneity: An experimental approach in the health and retirement Study'. The Quarterly Journal of Economics 112: 537-579.

Bassanini, Andrea., Alison Booth, Giorgio Brunello, Maria De Paola and Edwin Leuven 2006. 'Workplace training in Europe'. Bonn: IZA Discussion Paper n.1640.

Bell, Brian, and Michael Pitt 1988. 'Trade Union Decline and the Distribution of Earnings in the UK: Evidence from kernel density estimation.'. Oxford Bulletin of Economics and Statistics 60: 509-528.

Black, Boyd 2001. 'National Culture and Industrial Relations and Pay Structures'. Labour 15 (2). p 257-77.

Blanchflower, David and Richard B. Freeman 1997. 'The Attitudinal Legacy of Communist Labor Relations'. Industrial and Labor Relations Review 50: 438-459.

Blanchflower, David G. 1996. 'The Role and Influence of Trade Unions in the OECD' Centre for Economic Performance Discussion Paper. London: LSE.

Blanchflower, D. 2006. A cross-country study of union membership. IZA Discussion Paper n.2016

Blau, Francine, and Lawrence Kahn 1996. 'International Differences in Male Wage Inequality. Institutions versus market forces'. Journal of Political Economy 104: 791837.

Booth, Alison L. 1984. 'A Public Choice Model of Trade Union Behaviour and Membership.'. Economic Journal 94(376): 883-898.

Booth, Alison L. 1985. 'The Free Rider Problem and a Social Custom Theory of Trade Union Membership'. The Quarterly Journal of Economics 100: 253-261. 
Brown, William, Simon Deakon, M. Hudson, C. Pratten, and Paul Ryan 1998. 'The Individualisation of Employment Contracts in Britain'. London: Department of Trade and Industry, research paper.

Burda, Michael C. 1995. Unions and Wage Insurance. London: CEPR Discussion Paper, no. 1232.

Calmfors, Lars, Alison Booth, Michael Burda, Daniele Checchi, Robin Naylor and Jelle Visser 2001. 'The Role of Collective Bargaining in Europe' in T. Boeri, A. Brugiavini and L. Calmfors (ed.) The Role of the Unions in the Twenty-First Century. Oxford: Oxford University Press.

Card, David 1996. 'The Effects of Unions on the Structure of Wages: A longitudinal analysis'. Econometrica 64: 957-979.

Card, David 1998. 'Falling Union Membership and Rising Wage Inequality. What's the connection?' NBER Working Paper 6520. Cambridge, MA.

Card, David 2001. 'The Effect of Unions on Wage Inequality in the U.S. Labor Market'. Industrial and Labor Relations Review 54: 296-315.

Card, David, Francis Kramarz, and Thomas Lemieux 1999. 'Changes in the Relative Structure of Wages and Employment'. Canadian Journal of Economics 32: 843-877.

Card, D, T. Lemieux and C. Riddell. 2003. 'Unions and the wage structure'. in John T. Addison and C. Schnabel, eds. International Handbook of Trade Unions. Cheltenham, UK: Edward Elgar, pp. 246-292

Checchi, Daniele, and Jelle Visser 2005. 'Pattern Persistence in European Trade Union Density - A longitudinal analysis 1950-1996'. European Sociological Review 21: 1-22.

Crouch, Colin 1982. Trade Unions. The logic of collective action. Glasgow: Fontana.

Deininger, K. and L.Squire 1996. 'Measuring income inequality: a new data base'. The World Bank Economic Review 10: 565-591.

DiNardo, John, Nicole M. Fortin and Thomas Lemieux 1996. 'Labor Market Institutions and the Distribution of Wages, 1973-1992: A semi-parametric approach'. Econometrica 64: 1001-1044.

Ebbinghaus, Bernhard, and Jelle Visser 2000. Trade Unions in Western Europe since 1945. London: Palgrave-Macmillan.

Elias, Peter. 1996. 'Growth and decline in trade union membership in Great Britain: Evidence from work histories' in D. Gallie, R. Penn and M. Rose (eds.) Trade Unionism in Recession. Oxford: Oxford University Press, pp. 175-215.

European Commission, DG Employment and Social Affairs 2005. 'Earnings Disparities and Determinants of Earnings Distributions in the EU, chapter 4 in Employment in Europe 2005'. Brussels.

European Commission, DG for Employment, Industrial Relations and Social Affairs 2004. 'Industrial Relations in Europe, 2004'. Luxembourg: Office for the Official Publication of the European Communities.

Fehr, Ernst, and Simon Gachter 2002. 'Altruistic Punishment in Humans'. Nature: 137-140.

Flanders, Alan 1970. Management and Unions. The theory and reform of industrial relations. London: Faber and Faber.

Frank, Robert H., and Philip J. Cook 1995. The Winner-Take-All-Society. New York: The Free Press.

Freeman, Richard B. 1980. 'Unionism and the Dispersion of Wages'. Industrial and Labor Relations Review 34: 489-509.

Freeman, Richard B. 2005. 'What Do Unions Do? The 2004 M-Brane Stringtwister edition' NBER working paper 11410. Cambridge, MA.

Freeman, Richard B., and James L. Medoff 1984. What Do Unions Do? New York: Basic Books. 
Goerke, Lazlo and Markus Pannenberg 2004. 'Norm-Based Trade Union Membership: Evidence for Germany'. German Economic Review 5: 481-504.

Gosling, Amanda, and Steve Machin 1995. 'Trade Unions and the Dispersion of Earnings in UK Establishments 1980-90'. Oxford Bulletin of Economics and Statistics 57: 167-184.

Gottschalk, Peter, and Mary Joyce 1998. 'Cross-National Differences in the Rise in Earnings Inequality: Market and institutional factors'. The Review of Economics and Statistics LXXX: 489-502.

Hartog, Joop, Ada Ferrer-i-Carbonell, and Nicole Jonker 2002. 'Linking Measured Risk Aversion to Individual Characteristics'. Kyklos 55: 2-16.

Hechter, Michael 1987. Principles of group solidarity. Berkeley, CA: University of California Press.

Heery, Edward 2000. 'Trade Unions and the Management of Reward' in White, G.a.J. Drucker (ed.) Reward Management: Critical perspectives. London: Routledge, .

Hibbs, Douglas A. Jr., and Hakan Locking 1996. 'Wage Compression, Wage Drift and Wage Inflation in Sweden'. Labour Economics 3: 109-141.

Horn, Henrik, and Asher Wolinsky 1988. 'Worker Substitutability and Patterns of Unionization'. Economic Journal 98: 484-497.

Iversen, Torben 1999. Contested Economic Institutions. The Politics of Macroeconomics and Wage Bargaining in Advanced Democracies. Cambridge, Mass.: Cambridge University Press.

Jasso, Guilermina 1999. 'How Much Injustice is There in the World? Two new justice indexes'. American Sociological Review 64: 133-168.

Katz, Harry and Owen Darbishire 2000. Converging Divergences. Ithaca, N.Y.: Cornell University Press.

Klandermans, Bert, and Jelle Visser (ed.) 1995. De vakbeweging na de welvaartsstaat. Assen: Van Gorcum.

Lindbeck, Assar, and Dennis J. Snower 2001. 'Centralized Bargaining and Reorganised Work: Are they compatible?'. European Economic Review 45: 1851-1875.

Marginson, Paul, and Sisson, Keith 2004. European Integration and Industrial Relations. Multi-level governance in the making. London: Palgrave-Macmillan.

Martin, John P. 2000. 'What works among active labour market policies: evidence from OECD countries' experiences'. OECD Economic Studies 30: 79-113.

Metcalf, David 1982. 'Unions and the Distribution of Earnings'. British Journal of Industrial Relations 16: 163-179.

Metcalf, David 2005. 'British Unions: Resurgence or Perdition?'. London: The Work Foundation.

Metcalf, David, Kristine Hansen, and Andy Charlwood 2001. 'Unions and the Sword of Justice: Unions and pay systems, pay inequality, pay discrimination and low pay'. National Institute Economic Review 176: 61-75

Mosher, Jim 2002. 'Distributional Politics in Labor Unions' American Political Science Association, Annual Meeting. Boston, MA.

Naylor, Robin 1990. 'A social custom model of collective action'. European Journal of Political Economy 6: 201-216.

OECD 1996. 'Earnings Inequality, Low-Paid Employment and Earnings Mobility'. OECD Employment Outlook 1996: 59-108.

OECD 2004. 'Wage-Setting Institutions and Outcomes'. Employment Outlook 2004: 127182.

Osberg, Lars, and Timothy Smeeding 2006. '"Fair Inequality"? Attitudes toward pay differentials: the United States in comparative perspective'. American Sociological Review 71: 450-473. 
Pontusson, Jonas, and Peter Svenson 1996. 'Labor Markets, Production Strategies, and Wage Bargaining Institutions. The Swedish employer offensive in comparative perspective'. Comparative Political Studies 29: 223-250.

Pontusson, Jonas, David Rueda, and Christopher R. Way 2002. 'Comparative Political Economy of Wage Distribution: The role of partisanship and labour market institutions'. British Journal of Political Science 32: 281-308.

Reynolds, Lloyd G. 1951. The Structure of Labor Markets. Wages and Labor Mobility in Theory and Practice. New York: Harper.

Rueda, David, and Jonas Pontusson 2000. 'Wage Inequality and Varieties of Capitalism'. World Politics 52.

Schnabel, Claus, and Joachim Wagner 2003. 'Trade Union Membership in Eastern and Western Germany: Convergence or divergence?'. Bonn: IZA DP No. 707.

Schnabel, Claus and Joachim Wagner 2005, Determinants of Union Membership in 18 EU Countries: Evidence from Micro Data, 2002/03 - IZA Discussion Paper No. 1464 January

Slichter, Sumner 1950. 'Notes on the Structure of Wages'. Review of Economics and Statistics 32.

Streeck, Wolfgang 1992. Social Institutions and Economic Performance: Studies of industrial relations in advanced capitalist economies. London: Sage.

Streeck, Wolfgang 2005. 'Labor Markets and Trade Unions' in N.J. Smelser and R.Swedberg (ed.) The Handbook of Economic Sociology. Princeton and Oxford: Princeton University Press, with Russell Sage Foundation.

Svalfors, Steven 1997. 'Worlds of Welfare and Attitudes to Redistribution: A comparison of eight western nations'. European Sociological Review 13: 83-104.

Svallfors, Stefan 1993. 'Dimensions of Inequality: A comparison of attitudes in Sweden and Britain'. European Sociological Review 9: 67-287.

Svensen, P. 1989. Fair Shares. Unions, Pay, and Politics in Sweden and West Germany. Ithaca N.Y: Cornell University Press.

Teulings, Coen, and Joop Hartog 1998. Corporatism or Competition. Labour contracts, institutions and wage structures in international comparison. Cambridge, UK: Cambridge University Press.

Visser, Jelle 1990. 'In Search of Inclusive Unionism'. Bulletin of Comparative Labour Relations 18: 5-278.

Visser, Jelle 2002. 'Why Fewer European Workers Join Unions - A social customs explanation of membership trends'. British Journal of Industrial Relations 40: 403430.

Visser, Jelle 2006. 'Union Membership Statistics in 24 Countries'. Monthly Labor Review: $38-49$.

Wallerstein, Michael 1999. 'Wage-Setting Institutions and Pay Inequality in Advanced Industrial Societies'. American Journal of Political Science 43: 649-80.

Werfhorst, Herman G. van de, and Nan Dirk De Graaf 2004. 'The Sources of Political Orientations in Post-Industrial Society: Social class and education revisited'. British Journal of Sociology 55: 211-235.

Western, Bruce 1997. Between Capital and Class: Postwar unionization in the capitalist democracies. Princeton NJ: Princeton University Press. 
Figure 1 - Union membership and income inequality - macro evidence (source: Deininger-Squire 1996 and Ebbinghaus-Visser 2000)
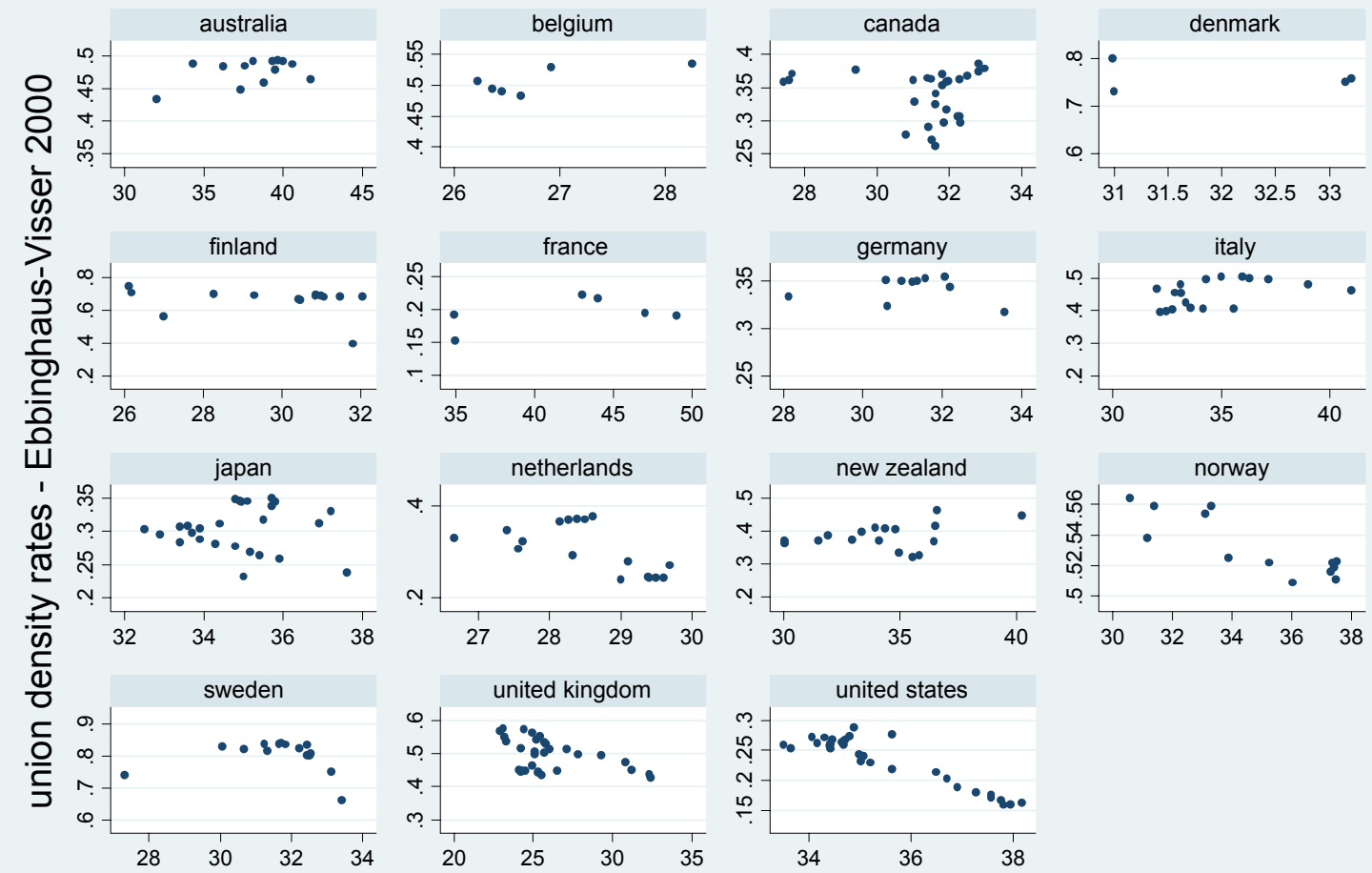

Gini index on total incomes - Deininger-Squire 1996 - high quality data 
Figure 2 - Union membership and income/earnings inequality - micro evidence (source: ISSP)
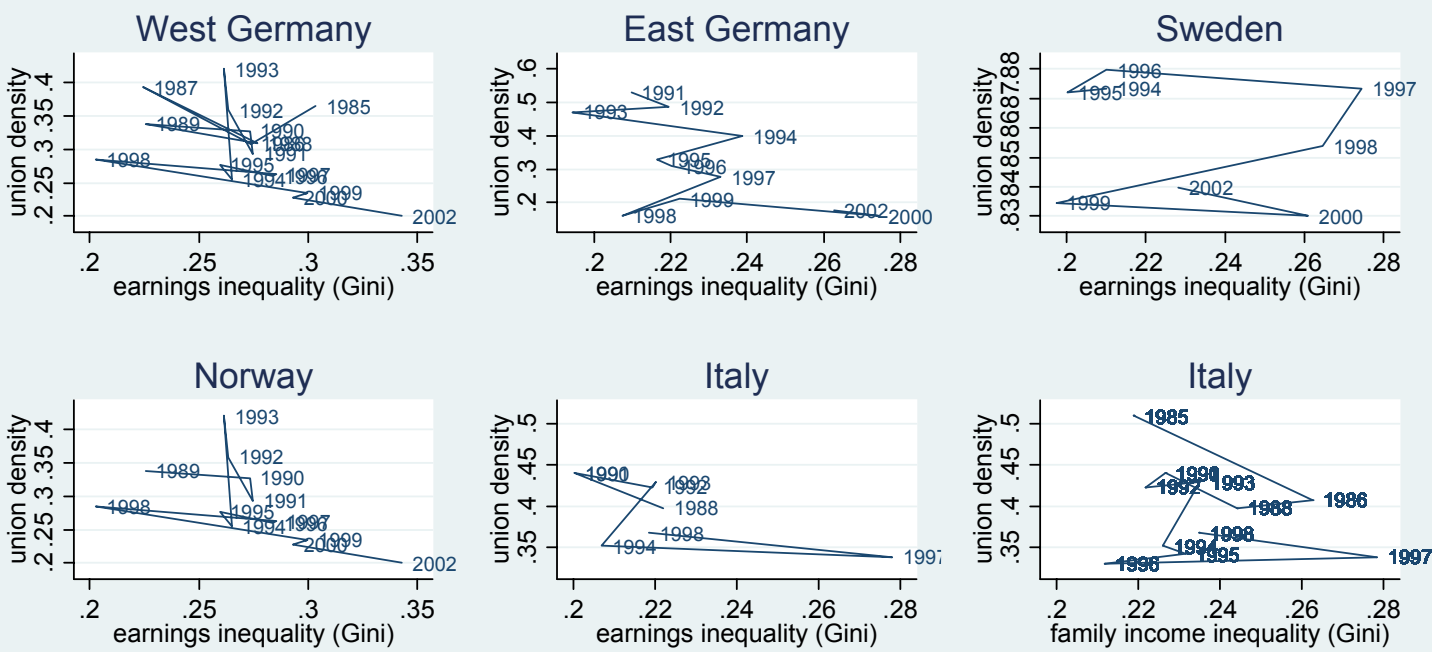

Netherlands

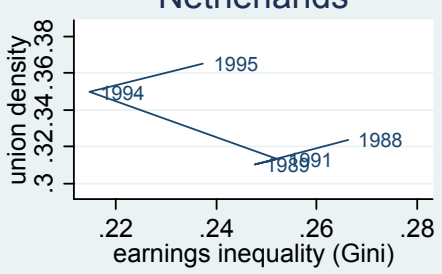

Netherlands

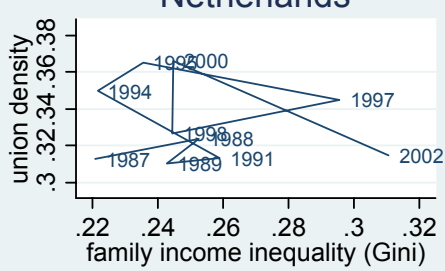

Britain

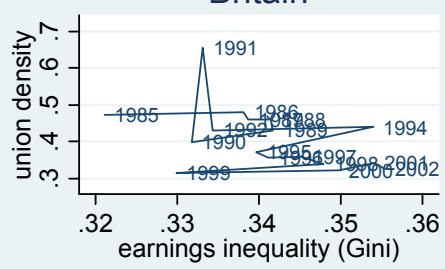


Figure 3 - Union density rates: comparison between macro and micro evidence

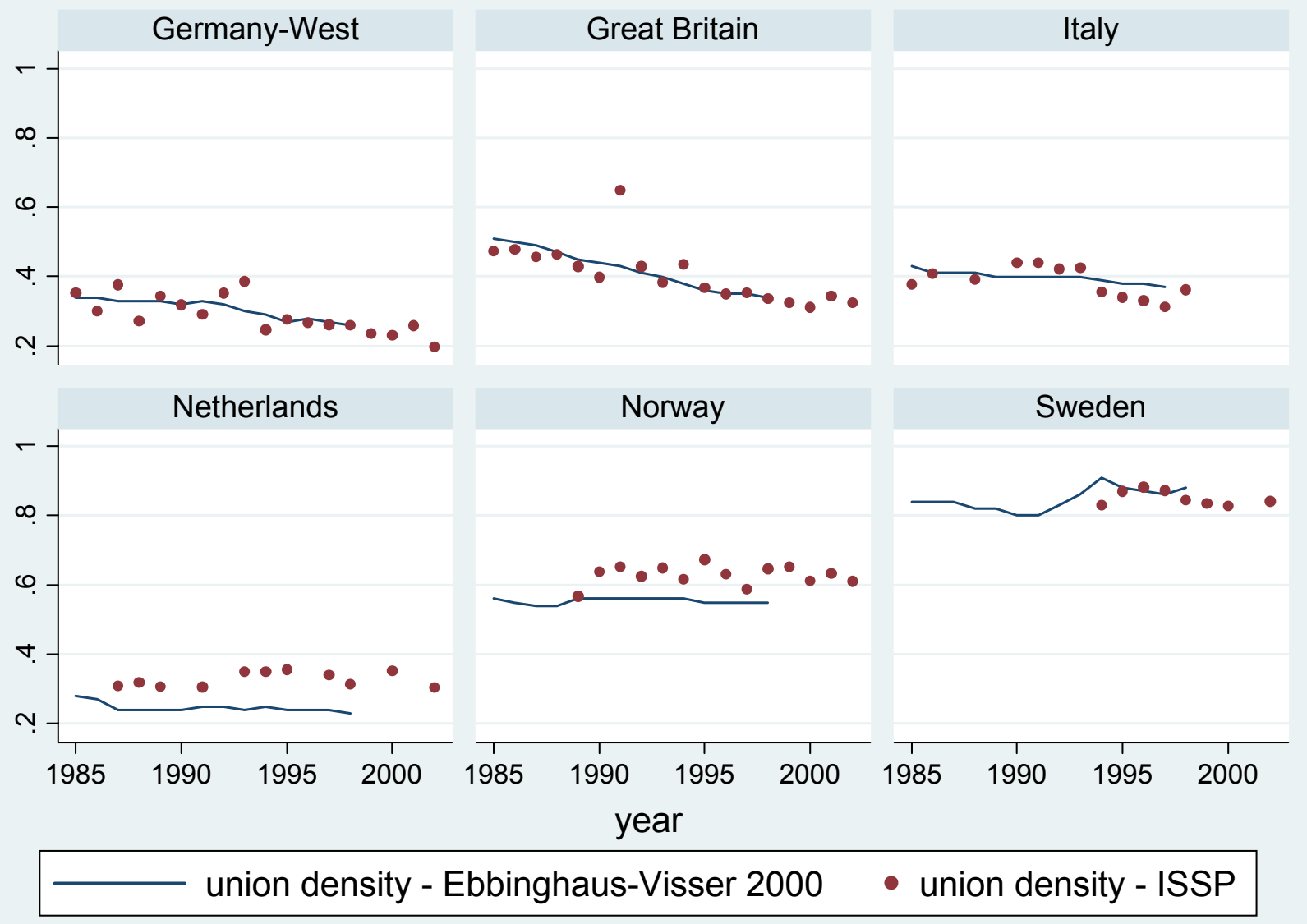


Figure 4 - Trends in inequality attitudes

Inequality tolerance

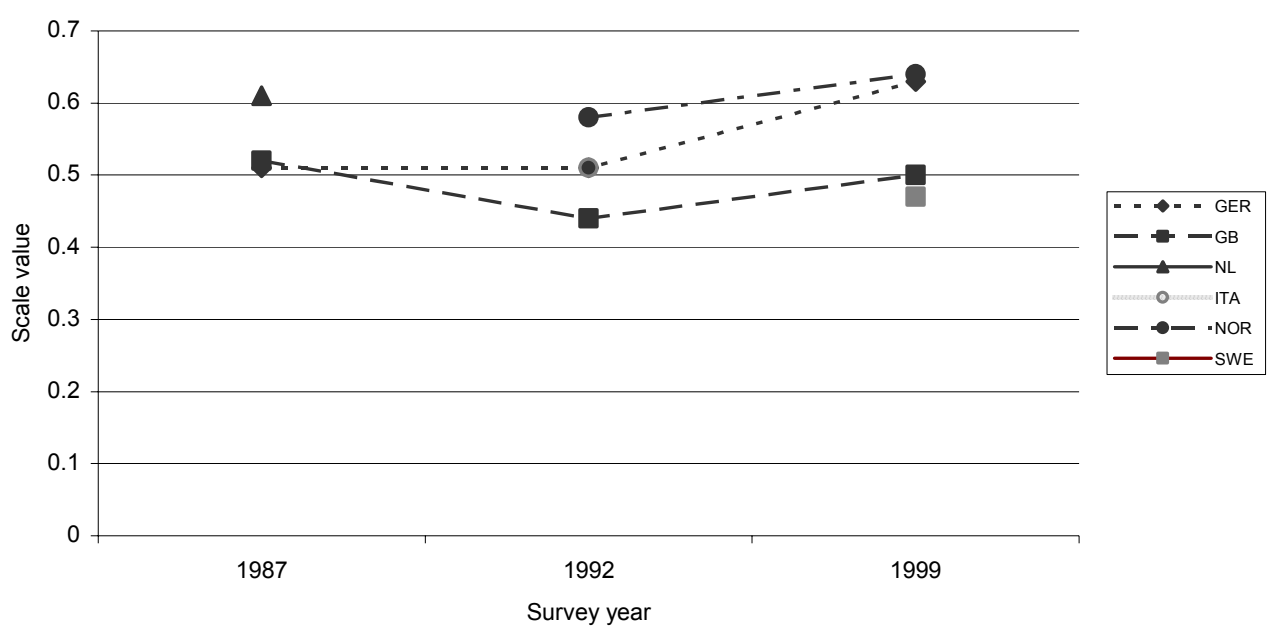

general inequality attitude
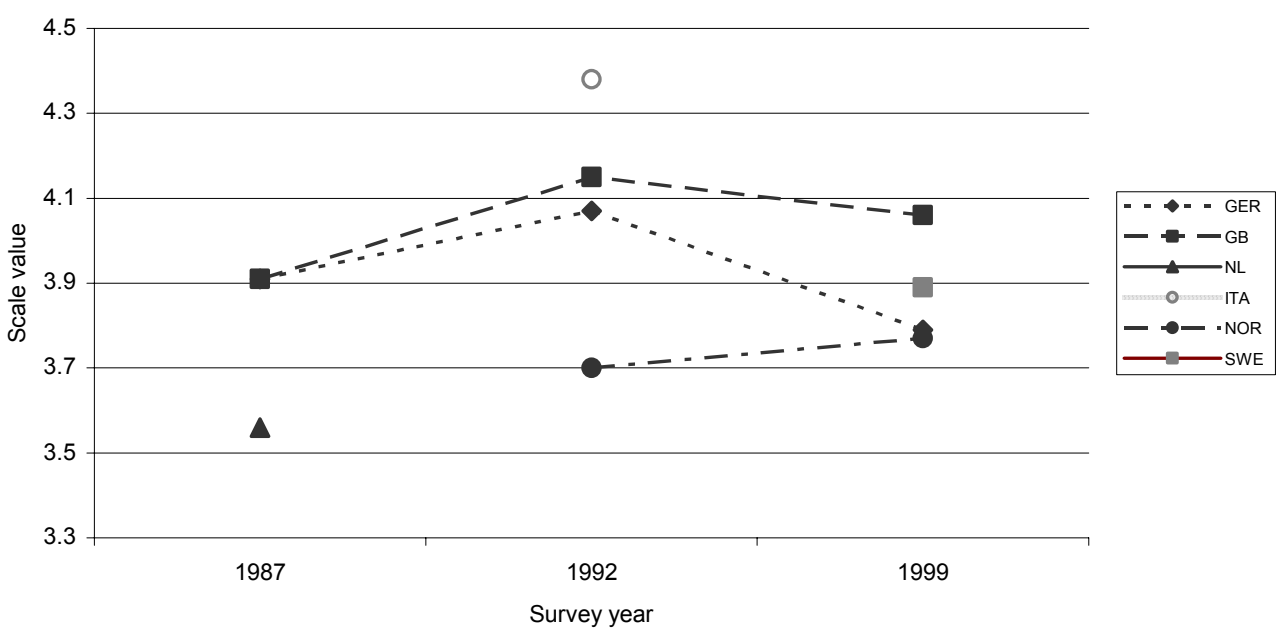

Inequality needs collective action

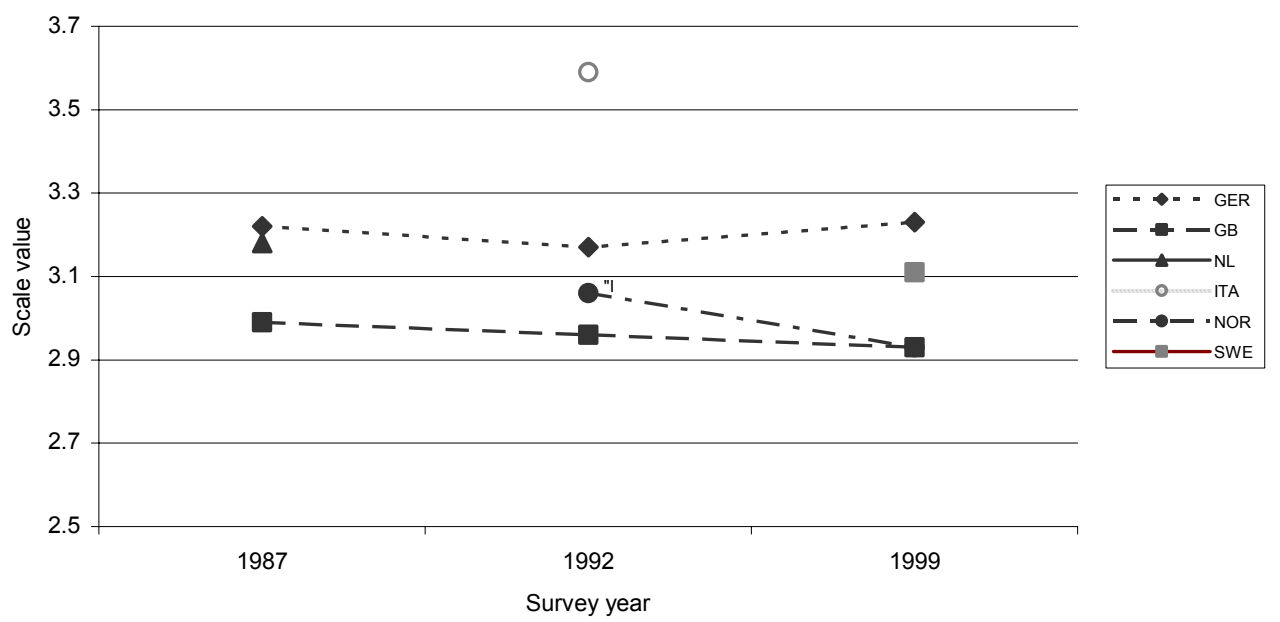


Figure 5 - Kernel density estimates of inequality permissiveness, by trade union membership status
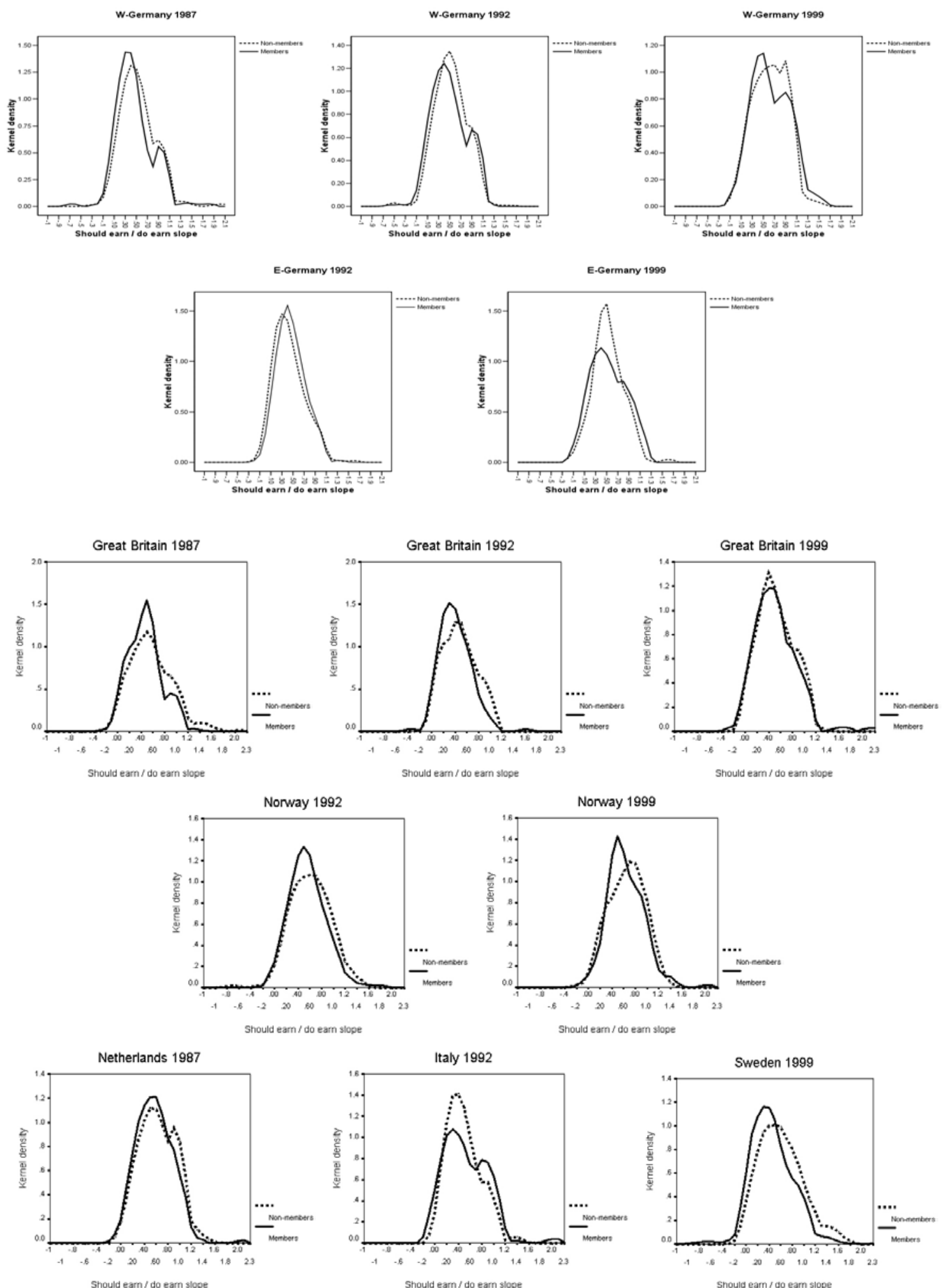
Figure 6 - Changes over time of relative earnings position on membership probability

$\%$ distance from median earnings - above

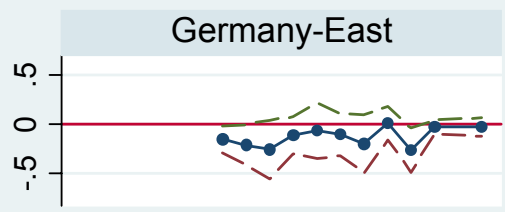

Germany-West

Great Britain
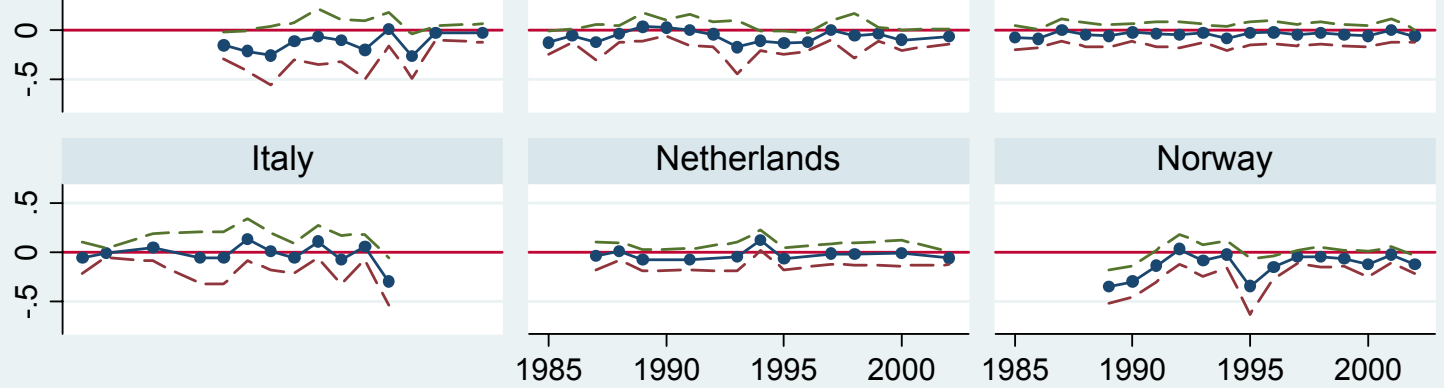

Sweden

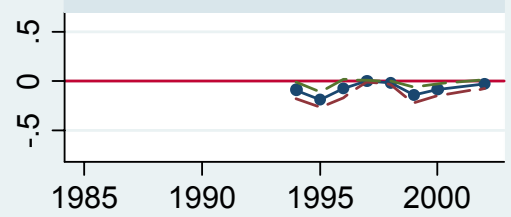

year

$\longrightarrow \%$ distance from median - above $\quad-----$-1.96 S.E.

-----+1.96 S.E.

$\%$ distance from median earnings - below

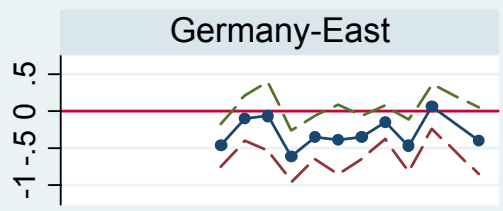

Germany-West

Great Britain
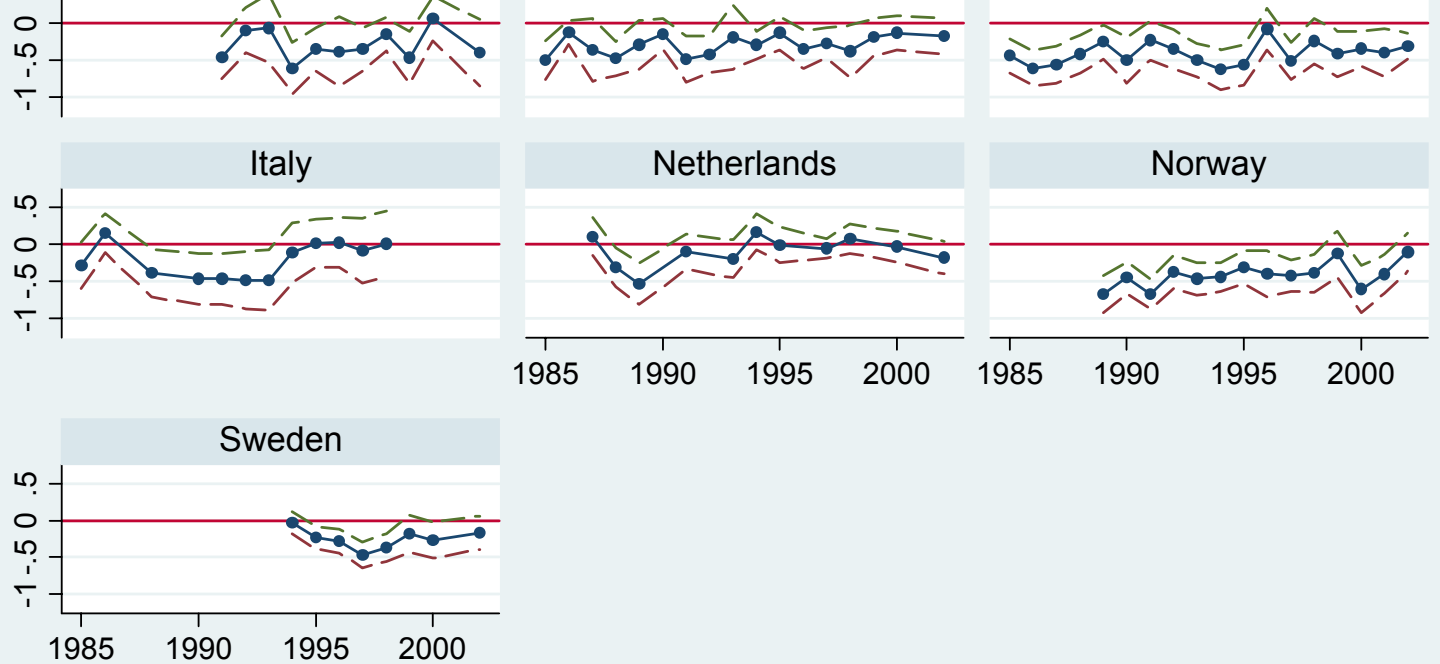

year

_ — \% distance from median earnings - below -1.96 S.E. -----+1.96 S.E. 
Table 1 - Probit regression of union membership (marginal effects) - ISSP 1985-2002

\begin{tabular}{|c|c|c|c|c|c|c|c|}
\hline & $\begin{array}{c}\text { West } \\
\text { Germany }\end{array}$ & $\begin{array}{c}\text { East } \\
\text { Germany }\end{array}$ & Sweden & Norway & Italy & Netherlands & Britain \\
\hline Female & $\begin{array}{c}-0.133 \\
{[0.012]^{\star \star \star}}\end{array}$ & $\begin{array}{l}-0.031 \\
{[0.020]}\end{array}$ & $\begin{array}{c}0.016 \\
{[0.012]}\end{array}$ & $\begin{array}{c}-0.022 \\
{[0.013]^{\star}}\end{array}$ & $\begin{array}{c}-0.091 \\
{[0.021]^{\star \star \star}}\end{array}$ & $\begin{array}{c}-0.112 \\
{[0.016]^{\star \star \star}}\end{array}$ & $\begin{array}{c}-0.072 \\
{[0.014]^{\star \star *}}\end{array}$ \\
\hline \multirow[t]{2}{*}{ Young } & -0.053 & -0.074 & -0.07 & -0.144 & -0.152 & -0.143 & -0.08 \\
\hline & {$[0.012]^{\star \star \star}$} & {$[0.023]^{\star \star *}$} & {$[0.015]^{\star \star *}$} & {$[0.015]^{\star \star \star}$} & {$[0.026]^{\star \star *}$} & {$[0.014]^{\star \star \star}$} & {$[0.014]^{\star \star *}$} \\
\hline \multirow[t]{2}{*}{ Married } & 0.016 & -0.011 & 0.023 & 0.047 & 0.076 & 0.003 & 0.033 \\
\hline & {$[0.011]$} & {$[0.021]$} & {$[0.011]^{\star \star}$} & {$[0.012]^{\star \star \star}$} & {$[0.023]^{\star \star \star}$} & {$[0.013]$} & {$[0.012]^{\star \star \star}$} \\
\hline \multirow[t]{2}{*}{ working less than fulltime } & -0.09 & 0.081 & 0.012 & -0.054 & -0.106 & -0.029 & -0.037 \\
\hline & {$[0.016]^{\star \star \star}$} & {$[0.030]^{\star \star \star}$} & {$[0.015]$} & {$[0.019]^{\star \star \star}$} & {$[0.029]^{\star \star \star}$} & {$[0.016]^{\star}$} & {$[0.018]^{\star \star}$} \\
\hline \multirow[t]{2}{*}{ working for government/public owned } & 0.127 & 0.085 & 0.139 & 0.399 & 0.187 & 0.16 & 0.412 \\
\hline & {$[0.012]^{\star \star \star}$} & {$[0.020]^{\star \star \star}$} & {$[0.011]^{\star \star \star}$} & {$[0.010]^{\star \star *}$} & {$[0.022]^{\star \star \star}$} & {$[0.014]^{\star \star \star}$} & {$[0.013]^{* \star *}$} \\
\hline \multirow[t]{2}{*}{ supervising someone } & -0.039 & 0.013 & -0.059 & -0.03 & 0.073 & 0.005 & -0.057 \\
\hline & {$[0.012]^{\star \star \star}$} & {$[0.021]$} & {$[0.010]^{\star \star \star}$} & {$[0.012]^{\star \star}$} & {$[0.026]^{\star \star \star}$} & [0.013] & {$[0.012]^{\star * *}$} \\
\hline \multirow[t]{2}{*}{ upper secondary completed } & -0.055 & -0.07 & -0.066 & 0.003 & -0.028 & -0.006 & -0.025 \\
\hline & {$[0.017]^{\star \star \star}$} & {$[0.036]^{\star \star}$} & {$[0.016]^{\star \star \star}$} & {$[0.014]$} & [0.022] & {$[0.016]$} & {$[0.016]$} \\
\hline \multirow[t]{2}{*}{ beyond secondary/incomplete college } & -0.077 & 0.02 & -0.081 & -0.028 & 0.011 & 0.027 & -0.005 \\
\hline & {$[0.020]^{\star \star \star}$} & [0.039] & {$[0.023]^{\star \star \star}$} & {$[0.017]$} & [0.034] & [0.022] & {$[0.016]$} \\
\hline \multirow{2}{*}{ university degree completed } & -0.137 & -0.062 & -0.073 & -0.043 & -0.12 & -0.086 & -0.125 \\
\hline & {$[0.017]^{\star \star \star}$} & {$[0.036]^{\star}$} & {$[0.019]^{\star \star \star}$} & {$[0.020]^{\star \star}$} & {$[0.037]^{\star \star \star}$} & {$[0.019]^{\star \star \star}$} & {$[0.021]^{\star \star \star}$} \\
\hline \multirow[t]{2}{*}{ female*college completed } & 0.184 & 0.049 & 0.034 & 0.098 & 0.078 & 0.168 & 0.165 \\
\hline & {$[0.040]^{\star \star \star}$} & {$[0.058]$} & {$[0.018]^{\star}$} & {$[0.022]^{\star \star *}$} & [0.064] & {$[0.032]^{\star \star \star}$} & {$[0.032]^{\star \star \star}$} \\
\hline \multirow[t]{2}{*}{ Relative distance from the median earnings (above) } & -0.06 & -0.115 & -0.012 & -0.078 & -0.025 & -0.029 & -0.04 \\
\hline & {$[0.014]^{\star \star \star}$} & {$[0.031]^{\star \star \star}$} & {$[0.006]^{*}$} & {$[0.015]^{\star \star *}$} & {$[0.018]$} & {$[0.016]^{*}$} & {$[0.013]^{\star \star *}$} \\
\hline \multirow[t]{2}{*}{ Relative distance from the median earnings (below) } & -0.266 & -0.309 & -0.239 & -0.403 & -0.126 & -0.077 & -0.409 \\
\hline & {$[0.030]^{\star \star \star}$} & {$[0.053]^{\star \star \star}$} & {$[0.035]^{\star \star \star}$} & {$[0.033]^{\star \star \star}$} & {$[0.055]^{\star *}$} & {$[0.031]^{\star *}$} & {$[0.030]^{\star * *}$} \\
\hline Observa & 8842 & 3141 & 4902 & 10040 & 2988 & 7066 & 9269 \\
\hline Pseudo R-squared & 0.08 & 0.09 & 0.11 & 0.18 & 0.09 & 0.05 & 0.16 \\
\hline Log likelihood & -4968.21 & -1868.54 & -1767.37 & -5409.28 & -1833.67 & -4286.49 & -5299.54 \\
\hline
\end{tabular}


Table 2 - Probit regression of union membership including attitudinal variables (marginal effects) ISSP 1987, 1992, 1999 - all countries

\begin{tabular}{|c|c|c|c|c|}
\hline & Model 0 & Model 1 & Model 2 & Model 3 \\
\hline female & $\begin{array}{c}-0.049 \\
{[0.018]^{\star \star \star}}\end{array}$ & $\begin{array}{c}-0.05 \\
{[0.018]^{\star \star \star}}\end{array}$ & $\begin{array}{c}-0.05 \\
{[0.018]^{\star \star \star}}\end{array}$ & $\begin{array}{c}-0.048 \\
{[0.018]^{\star \star \star}}\end{array}$ \\
\hline \multirow[t]{2}{*}{ young } & -0.125 & -0.117 & -0.118 & -0.115 \\
\hline & {$[0.021]^{\star \star \star}$} & {$[0.021]^{\star \star *}$} & {$[0.021]^{\star \star \star}$} & {$[0.021]^{\star \star \star}$} \\
\hline \multirow[t]{2}{*}{ married } & 0.031 & 0.032 & 0.033 & 0.034 \\
\hline & {$[0.019]$} & {$[0.019]^{\star}$} & {$[0.019]^{\star}$} & {$[0.019]^{\star}$} \\
\hline \multirow[t]{2}{*}{ working less than fulltime } & -0.103 & -0.103 & -0.104 & -0.104 \\
\hline & {$[0.024]^{\star \star \star}$} & {$[0.024]^{\star \star *}$} & {$[0.024]^{\star \star \star}$} & {$[0.025]^{\star \star \star}$} \\
\hline \multirow[t]{2}{*}{ work for government/public owned } & 0.27 & 0.267 & 0.266 & 0.266 \\
\hline & {$[0.016]^{\star \star \star}$} & {$[0.016]^{\star \star *}$} & {$[0.016]^{\star \star \star}$} & {$[0.016]^{\star \star \star}$} \\
\hline \multirow[t]{2}{*}{ supervising someone } & -0.032 & -0.022 & -0.021 & -0.021 \\
\hline & {$[0.018]^{\star}$} & [0.018] & {$[0.018]$} & {$[0.018]$} \\
\hline \multirow[t]{2}{*}{ upper secondary completed } & -0.072 & -0.067 & -0.068 & -0.07 \\
\hline & {$[0.023]^{\star \star \star}$} & {$[0.023]^{\star \star *}$} & {$[0.023]^{\star \star \star}$} & {$[0.023]^{\star \star \star}$} \\
\hline \multirow[t]{2}{*}{ beyond secondary/incomplete college } & -0.008 & 0.014 & 0.012 & 0.012 \\
\hline & {$[0.027]$} & {$[0.027]$} & {$[0.027]$} & {$[0.027]$} \\
\hline \multirow[t]{2}{*}{ university degree completed } & -0.02 & -0.001 & 0 & -0.001 \\
\hline & {$[0.026]$} & {$[0.027]$} & {$[0.027]$} & $\begin{array}{c}{[0.027]} \\
-0.084\end{array}$ \\
\hline Relative distance from the median earnings (above) & $\begin{array}{c}-0.109 \\
{[0.024]^{\star * *}}\end{array}$ & $\begin{array}{c}-0.084 \\
{[0.024]^{\star \star \star}}\end{array}$ & $\begin{array}{c}-0.062 \\
{[0.027]^{\star \star}}\end{array}$ & $\begin{array}{c}-0.084 \\
{[0.024]^{\star \star *}}\end{array}$ \\
\hline Relative distance from the median earnings (below) & $\begin{array}{c}-0.267 \\
{[0.045]^{\star \star \star}}\end{array}$ & $\begin{array}{c}-0.27 \\
{[0.046]^{\star \star *}}\end{array}$ & $\begin{array}{c}-0.25 \\
{[0.046]^{\star \star \star}}\end{array}$ & $\begin{array}{c}-0.274 \\
{[0.046]^{\star \star \star}}\end{array}$ \\
\hline inequality tolerance & & $\begin{array}{c}-0.018 \\
{[0.009]^{\star \star}}\end{array}$ & $\begin{array}{c}-0.02 \\
{[0.012]^{\star}}\end{array}$ & $\begin{array}{c}-0.054 \\
{[0.018]^{\star \star \star}}\end{array}$ \\
\hline \multirow{2}{*}{ general inequality attitude } & & 0.039 & 0.038 & 0.036 \\
\hline & & {$[0.009]^{\star \star *}$} & {$[0.013]^{\star \star *}$} & {$[0.018]^{\star \star}$} \\
\hline \multirow[t]{2}{*}{ collective action inequality attitude } & & 0.016 & 0.01 & 0.014 \\
\hline & & {$[0.009]^{\star}$} & {$[0.013]$} & {$[0.016]$} \\
\hline Distance earnings (below) ×tolerance for inequality attitude & & & $\begin{array}{c}0.039 \\
{[0.046]}\end{array}$ & \\
\hline \multirow[t]{2}{*}{ Distance earnings (above) ×tolerance for inequality attitude } & & & -0.007 & \\
\hline & & & {$[0.026]$} & \\
\hline \multirow{2}{*}{ Distance earnings (below) $\times$ general inequality attitude } & & & -0.034 & \\
\hline & & & {$[0.046]$} & \\
\hline \multirow[t]{2}{*}{ Distance earnings (above) $\times$ general inequality attitude } & & & 0.017 & \\
\hline & & & [0.024] & \\
\hline \multirow[t]{2}{*}{ Distance earnings (below) $\times$ collective action inequality attitude } & & & 0.009 & \\
\hline & & & {$[0.042]$} & \\
\hline \multirow[t]{2}{*}{ Distance earnings (above) $\times$ collective action inequality attitude } & & & 0.022 & \\
\hline & & & {$[0.024]$} & \\
\hline
\end{tabular}


1992×tolerance for inequality attitude

1999×tolerance for inequality attitude

1992×general inequality attitude

1999×general inequality attitude

1992×collective action inequality attitude

1999×collective action inequality attitude

1909xcollective action inequality attitude

Year 1992

$-0.021$

Year 1999

$[0.026$ $-0.026$

$\begin{array}{llll}-0.152 & -0.156 & -0.157 & -0.156\end{array}$

East Germany

$[0.028]^{\star \star \star}[0.028]^{\star \star \star} \quad[0.028]^{\star \star \star} \quad[0.028]^{\star \star \star}$

$\begin{array}{llll}0.029 & 0.039 & 0.042 & 0.037\end{array}$

Britain

$\left[\begin{array}{llll}0.033] & {[0.033]} & {[0.033]} & {[0.033]}\end{array}\right.$

$\begin{array}{llll}0.073 & 0.071 & 0.073 & 0.07\end{array}$

$[0.025]^{\star \star \star}[0.025]^{\star \star \star}[0.025]^{\star \star \star}[0.025]^{\star \star \star}$

Netherlands

$\begin{array}{llll}-0.121 & -0.122 & -0.117 & -0.123\end{array}$

Italy

$[0.035]^{\star \star \star}[0.035]^{\star \star \star}[0.035]^{\star \star \star}[0.035]^{\star \star \star}$

$\begin{array}{llll}0.01 & 0.02 & 0.022 & 0.02\end{array}$

$\left[\begin{array}{llll}0.037] & {[0.037]} & {[0.037]} & {[0.037]}\end{array}\right.$

Norway

$\begin{array}{llll}0.245 & 0.247 & 0.25 & 0.246\end{array}$

$[0.026]^{\star \star \star}[0.026]^{\star \star \star}[0.026]^{\star \star \star}[0.026]^{\star \star \star}$

Sweden

$\begin{array}{llll}0.503 & 0.508 & 0.511 & 0.509\end{array}$

Observations

$\begin{array}{cccc}{[0.018]^{\star \star \star}} & {[0.018]^{\star \star \star}} & {[0.018]^{\star \star \star}} & {[0.018]^{\star \star \star}} \\ 4461 & 4461 & 4461 & 4461\end{array}$

Pseudo R-squared

$\begin{array}{llll}0.16 & 0.16 & 0.17 & 0.17\end{array}$

Log likelihood

$\begin{array}{llll}-2595.04 & -2574.68 & -2571.59 & -2568.41\end{array}$

Robust standard errors in brackets - * significant at 10\%; ** significant at 5\%; *** significant at 1\% -

Missing values are replaced with sample averages, in order not to reduce sample size 
Table 3 - Probit regression of union membership on earnings position and inequality attitudes, by country - ISSP 1987, 1992, 1999

\begin{tabular}{|c|c|c|c|c|c|c|c|c|c|c|c|c|c|c|}
\hline & $\begin{array}{l}\text { West } \\
\text { Germany } \\
\text { Model } 1\end{array}$ & $\begin{array}{l}\text { West } \\
\text { Germany } \\
\text { Model } 2\end{array}$ & $\begin{array}{l}\text { East } \\
\text { Germany } \\
\text { Model } 1\end{array}$ & $\begin{array}{l}\text { East } \\
\text { Germany } \\
\text { Model } 2\end{array}$ & $\begin{array}{l}\text { Britain } \\
\text { Model } 1\end{array}$ & $\begin{array}{c}\text { Britain } \\
\text { Model } 2\end{array}$ & $\begin{array}{l}\text { Nether } \\
\text { lands } \\
\text { Model } 1\end{array}$ & $\begin{array}{l}\text { Nether } \\
\text { lands } \\
\text { Model } 2\end{array}$ & $\begin{array}{c}\text { Italy } \\
\text { Model } 1\end{array}$ & $\begin{array}{c}\text { Italy } \\
\text { Model } 2\end{array}$ & $\begin{array}{l}\text { Norway } \\
\text { Model } 1\end{array}$ & $\begin{array}{l}\text { Norway } \\
\text { Model } 2\end{array}$ & $\begin{array}{l}\text { Sweden } \\
\text { Model } 1\end{array}$ & $\begin{array}{l}\text { Sweden } \\
\text { Model } 2\end{array}$ \\
\hline \multirow[t]{2}{*}{$\overline{1992}$} & -0.014 & -0.014 & Ref. & Ref. & -0.043 & -0.046 & -- & -- & -- & -- & Ref. & Ref. & -- & -- \\
\hline & {$[0.039]$} & {$[0.039]$} & & & {$[0.039]$} & {$[0.039]$} & -- & -- & -- & -- & -- & -- & -- & -- \\
\hline \multirow[t]{2}{*}{1999} & -0.136 & -0.134 & -0.287 & -0.292 & -0.183 & -0.187 & -- & -- & -- & -- & 0.008 & 0.005 & -- & -- \\
\hline & {$[0.042]^{\star \star *}$} & {$[0.042]^{\star \star *}$} & {$[0.048]^{\star \star \star}$} & {$[0.049]^{\star \star \star}$} & {$[0.037]^{\star \star *}$} & {$[0.037]^{\star \star \star}$} & -- & -- & -- & -- & {$[0.046]$} & {$[0.046]$} & -- & -- \\
\hline \multirow[t]{2}{*}{ Female } & -0.096 & -0.093 & 0.003 & -0.001 & -0.047 & -0.051 & -0.043 & -0.045 & -0.079 & -0.108 & -0.044 & -0.058 & 0.034 & 0.035 \\
\hline & {$[0.038]^{* *}$} & {$[0.038]^{* *}$} & {$[0.054]$} & [0.055] & {$[0.037]$} & {$[0.037]$} & [0.063] & {$[0.063]$} & [0.067] & [0.068] & [0.041] & {$[0.042]$} & [0.038] & [0.038] \\
\hline \multirow[t]{2}{*}{ Young } & -0.049 & -0.045 & -0.077 & -0.066 & -0.086 & -0.085 & -0.111 & -0.105 & -0.324 & -0.307 & -0.159 & -0.166 & -0.095 & -0.094 \\
\hline & {$[0.041]$} & {$[0.042]$} & {$[0.060]$} & [0.061] & {$[0.039]^{\star *}$} & {$[0.039]^{\star *}$} & {$[0.053]^{\star *}$} & {$[0.053]^{\star *}$} & {$[0.081]^{\star \star *}$} & {$[0.088]^{\star \star \star}$} & {$[0.048]^{\star \star \star}$} & {$[0.049]^{\star \star \star}$} & {$[0.052]^{*}$} & {$[0.052]^{*}$} \\
\hline \multirow[t]{2}{*}{ Married } & 0.019 & 0.017 & -0.011 & 0.001 & -0.017 & -0.008 & 0.025 & 0.032 & 0.037 & 0.029 & 0.128 & 0.135 & 0.078 & 0.076 \\
\hline & {$[0.036]$} & {$[0.036]$} & {$[0.058]$} & [0.059] & {$[0.037]$} & {$[0.038]$} & {$[0.056]$} & {$[0.057]$} & {$[0.076]$} & {$[0.077]$} & {$[0.048]^{\star \star *}$} & {$[0.048]^{\star \star *}$} & {$[0.035]^{\star *}$} & {$[0.036]^{* *}$} \\
\hline \multirow[t]{2}{*}{ working less than fulltime } & -0.094 & -0.093 & 0.142 & 0.155 & -0.038 & -0.036 & -0.174 & -0.172 & -0.243 & -0.235 & -0.151 & -0.138 & -0.032 & -0.021 \\
\hline & {$[0.052]^{*}$} & {$[0.053]^{*}$} & {$[0.083]^{\star}$} & {$[0.085]^{\star}$} & {$[0.047]$} & {$[0.047]$} & {$[0.058]^{\star * *}$} & {$[0.058]^{\star \star *}$} & {$[0.085]^{\star * *}$} & {$[0.088]^{\star * *}$} & {$[0.068]^{* *}$} & {$[0.067]^{\star *}$} & {$[0.065]$} & [0.064] \\
\hline \multirow[t]{2}{*}{ work for government/public owned } & 0.153 & 0.153 & 0.091 & 0.085 & 0.4 & 0.397 & 0.114 & 0.114 & 0.251 & 0.261 & 0.365 & 0.373 & 0.1 & 0.106 \\
\hline & {$[0.038]^{\star * *}$} & {$[0.038]^{\star * *}$} & {$[0.059]$} & [0.059] & {$[0.031]^{\star * *}$} & {$[0.032]^{\star * *}$} & {$[0.048]^{\star *}$} & {$[0.049]^{* *}$} & {$[0.062]^{\star \star *}$} & {$[0.062]^{\star * *}$} & {$[0.036]^{\star * *}$} & {$[0.036]^{\star * *}$} & $*[0.037]^{\star * *}$ & {$[0.037]^{\star * *}$} \\
\hline \multirow[t]{2}{*}{ supervising someone } & -0.004 & -0.004 & 0.134 & 0.127 & -0.089 & -0.087 & -0.092 & -0.087 & 0.043 & 0.06 & -0.023 & -0.03 & -0.043 & -0.05 \\
\hline & {$[0.035]$} & {$[0.035]$} & {$[0.056]^{* *}$} & {$[0.057]^{\star *}$} & {$[0.035]^{\star * *}$} & {$[0.035]^{* *}$} & {$[0.052]^{\star}$} & {$[0.053]^{*}$} & [0.075] & [0.077] & [0.043] & {$[0.043]$} & [0.035] & {$[0.036]$} \\
\hline \multirow[t]{2}{*}{ upper secondary completed } & -0.069 & -0.071 & -0.167 & -0.17 & -0.043 & -0.043 & -0.06 & -0.059 & -0.078 & -0.074 & -0.069 & -0.072 & -0.046 & -0.044 \\
\hline & [0.053] & [0.053] & [0.108] & {$[0.110]$} & {$[0.045]$} & {$[0.045]$} & {$[0.070]$} & {$[0.069]$} & {$[0.069]$} & {$[0.069]$} & {$[0.054]$} & {$[0.055]$} & {$[0.043]$} & {$[0.045]$} \\
\hline \multirow[t]{2}{*}{ beyond secondary/incomplete college } & 0.027 & 0.034 & -0.263 & -0.246 & -0.012 & -0.013 & 0.02 & 0.021 & -0.045 & -0.048 & 0.004 & -0.003 & 0.05 & 0.051 \\
\hline & {$[0.115]$} & {$[0.117]$} & {$[0.128]^{\star \star}$} & {$[0.143]^{*}$} & {$[0.046]$} & {$[0.046]$} & {$[0.058]$} & {$[0.059]$} & [0.143] & [0.141] & [0.051] & [0.052] & {$[0.050]$} & {$[0.051]$} \\
\hline \multirow{2}{*}{ university degree completed } & -0.12 & -0.13 & -0.035 & -0.055 & -0.076 & -0.077 & -0.039 & -0.032 & -0.209 & -0.193 & 0.093 & 0.094 & 0.056 & 0.054 \\
\hline & {$[0.056]^{\star *}$} & {$[0.054]^{\star *}$} & [0.083] & [0.083] & [0.053] & [0.053] & [0.081] & [0.082] & {$[0.103]^{\star *}$} & {$[0.106]^{*}$} & {$[0.053]^{*}$} & {$[0.053]^{*}$} & [0.043] & [0.045] \\
\hline \multirow[t]{2}{*}{ Relative distance from the median earnings (above) } & -0.104 & -0.094 & -0.151 & -0.127 & 0.023 & 0.035 & 0.028 & 0.077 & 0.298 & 0.331 & -0.01 & 0.046 & -0.131 & -0.078 \\
\hline & {$[0.045]^{* *}$} & {$[0.050]^{*}$} & [0.094] & [0.105] & [0.044] & {$[0.049]$} & [0.082] & [0.098] & {$[0.142]^{\star *}$} & {$[0.141]^{* *}$} & {$[0.066]$} & {$[0.082]$} & {$[0.041]^{\star * *}$} & {$[0.064]$} \\
\hline \multirow[t]{2}{*}{ Relative distance from the median earnings (below) } & -0.373 & -0.373 & -0.133 & -0.142 & -0.413 & -0.398 & 0.038 & 0.043 & -0.109 & -0.063 & -0.109 & -0.065 & -0.259 & -0.249 \\
\hline & {$[0.104]^{\star \star \star}$} & {$[0.105]^{\star \star *}$} & {$[0.142]$} & {$[0.155]$} & {$[0.083]^{\star \star *}$} & {$[0.085]^{\star \star *}$} & {$[0.150]$} & {$[0.158]$} & {$[0.172]$} & {$[0.176]$} & {$[0.130]$} & {$[0.132]$} & {$[0.134]^{\star}$} & {$[0.134]^{*}$} \\
\hline \multirow[t]{2}{*}{ tolerance for inequality attitude } & -0.022 & -0.002 & 0.035 & 0.018 & -0.043 & -0.058 & -0.037 & -0.043 & 0.034 & 0.001 & -0.004 & -0.02 & -0.018 & -0.004 \\
\hline & {$[0.017]$} & {$[0.025]$} & {$[0.025]$} & [0.033] & {$[0.020]^{* *}$} & {$[0.026]^{* *}$} & {$[0.026]$} & [0.044] & [0.031] & [0.052] & [0.021] & [0.031] & [0.015] & [0.023] \\
\hline \multirow{2}{*}{ general inequality attitude } & 0.044 & 0.042 & -0.009 & 0.001 & 0.034 & 0.045 & 0.012 & -0.033 & 0.064 & 0.081 & 0.048 & 0.02 & 0.042 & 0.031 \\
\hline & {$[0.020]^{\star *}$} & {$[0.028]$} & {$[0.025]$} & {$[0.037]$} & {$[0.017]^{\star *}$} & {$[0.026]^{*}$} & {$[0.026]$} & [0.044] & {$[0.034]^{*}$} & [0.060] & {$[0.022]^{\star *}$} & [0.034] & {$[0.020]^{* *}$} & {$[0.028]$} \\
\hline \multirow[t]{2}{*}{ collective action inequality attitude } & 0.026 & 0.04 & 0.026 & -0.02 & 0.014 & -0.022 & -0.019 & -0.014 & -0.029 & -0.017 & 0.005 & 0.034 & 0.016 & 0.049 \\
\hline & {$[0.017]$} & {$[0.026]$} & {$[0.027]$} & {$[0.041]$} & {$[0.016]$} & {$[0.026]$} & {$[0.023]$} & {$[0.038]$} & {$[0.030]$} & {$[0.051]$} & {$[0.020]$} & [0.031] & {$[0.018]$} & {$[0.026]^{*}$} \\
\hline \multirow[t]{2}{*}{ distance earnings (below) $\times$ tolerance for inequality attitude } & & -0.063 & & 0.251 & & -0.034 & & 0.011 & & 0.126 & & 0.278 & & -0.022 \\
\hline & & {$[0.099]$} & & [0.154] & & {$[0.085]$} & & {$[0.161]$} & & [0.186] & & {$[0.106]^{\star \star *}$} & & {$[0.078]$} \\
\hline \multirow[t]{2}{*}{ distance earnings (above) ×tolerance for inequality attitude } & & -0.068 & & -0.155 & & 0.067 & & 0.014 & & 0.089 & & -0.068 & & -0.064 \\
\hline & & [0.052] & & {$[0.103]$} & & [0.041] & & [0.113] & & {$[0.137]$} & & {$[0.076]$} & & {$[0.040]$} \\
\hline \multirow[t]{2}{*}{ distance earnings (below) $\times$ general inequality attitude } & & 0.048 & & -0.011 & & -0.117 & & 0.11 & & -0.263 & & 0.176 & & -0.004 \\
\hline & & {$[0.086]$} & & {$[0.117]$} & & [0.078] & & {$[0.176]$} & & {$[0.186]$} & & [0.149] & & [0.121] \\
\hline distance earnings (above) $\times$ general inequality attitude & & -0.015 & & -0.04 & & 0.023 & & 0.154 & & 0.151 & & 0.047 & & 0.049 \\
\hline & & [0.043] & & [0.084] & & {$[0.044]$} & & [0.105] & & [0.141] & & [0.073] & & {$[0.047]$} \\
\hline distance earnings (below) $\times$ collective action inequality attitude & & -0.034 & & 0.252 & & 0.033 & & 0.018 & & 0.036 & & -0.056 & & -0.148 \\
\hline & & {$[0.097]$} & & [0.166] & & [0.067] & & [0.151] & & {$[0.160]$} & & [0.134] & & {$[0.107]$} \\
\hline Observations & 918 & 918 & 412 & 412 & 1160 & 1160 & 443 & 443 & 300 & 300 & 755 & 755 & 473 & 473 \\
\hline Pseudo R-squared & 0.1 & 0.1 & 0.1 & 0.12 & 0.17 & 0.18 & 0.06 & 0.06 & 0.16 & 0.18 & 0.17 & 0.19 & 0.18 & 0.19 \\
\hline Log likelihood & -538.79 & -537.5 & -246.02 & -241.83 & -654.87 & -647.47 & -257 & -255.86 & -172 & -168.76 & -412.73 & -405.8 & -177.81 & -175.54 \\
\hline
\end{tabular}


Table 4 - Trends in the impact of inequality attitudes on union membership, by country - probit model (marginal effects) - ISSP 1987, 1992, 1999

\begin{tabular}{|c|c|c|c|c|}
\hline & $\begin{array}{c}\text { West } \\
\text { Germany } \\
\text { Model } 3\end{array}$ & $\begin{array}{c}\text { East } \\
\text { Germany } \\
\text { Model } 3\end{array}$ & $\begin{array}{l}\text { Britain } \\
\text { Model } 3\end{array}$ & $\begin{array}{l}\text { Norway } \\
\text { Model } 3\end{array}$ \\
\hline 1992 & $\begin{array}{l}-0.005 \\
{[0.040]}\end{array}$ & Ref. & $\begin{array}{c}-0.038 \\
{[0.039]}\end{array}$ & Ref. \\
\hline 1999 & $\begin{array}{c}-0.125 \\
{[0.043]^{\star \star \star}}\end{array}$ & $\begin{array}{c}-0.297 \\
{[0.048]^{\star \star *}}\end{array}$ & $\begin{array}{c}-0.184 \\
{[0.037]^{\star * *}}\end{array}$ & $\begin{array}{c}0.013 \\
{[0.046]}\end{array}$ \\
\hline female & $\begin{array}{c}-0.096 \\
{[0.038]^{\star \star}}\end{array}$ & $\begin{array}{l}-0.009 \\
{[0.054]}\end{array}$ & $\begin{array}{l}-0.053 \\
{[0.037]}\end{array}$ & $\begin{array}{l}-0.047 \\
{[0.041]}\end{array}$ \\
\hline young & $\begin{array}{l}-0.047 \\
{[0.042]}\end{array}$ & $\begin{array}{l}-0.093 \\
{[0.061]}\end{array}$ & $\begin{array}{c}-0.081 \\
{[0.040]^{* *}}\end{array}$ & $\begin{array}{c}-0.154 \\
{[0.048]^{\star * *}}\end{array}$ \\
\hline married & $\begin{array}{c}0.022 \\
{[0.036]}\end{array}$ & $\begin{array}{l}-0.026 \\
{[0.060]}\end{array}$ & $\begin{array}{l}-0.011 \\
{[0.038]}\end{array}$ & $\begin{array}{c}0.132 \\
{[0.049]^{\star \star *}}\end{array}$ \\
\hline working less than fulltime & $\begin{array}{c}-0.089 \\
{[0.053]^{*}}\end{array}$ & $\begin{array}{c}0.132 \\
{[0.085]}\end{array}$ & $\begin{array}{l}-0.045 \\
{[0.047]}\end{array}$ & $\begin{array}{c}-0.154 \\
{[0.067]^{* *}}\end{array}$ \\
\hline work for government/public owned & $\begin{array}{c}0.153 \\
{[0.038]^{\star * *}}\end{array}$ & $\begin{array}{c}0.079 \\
{[0.059]}\end{array}$ & $\begin{array}{c}0.399 \\
{[0.032]^{\star \star *}}\end{array}$ & $\begin{array}{c}0.366 \\
{[0.036]^{\star * *}}\end{array}$ \\
\hline supervising someone & $\begin{array}{l}-0.003 \\
{[0.035]}\end{array}$ & $\begin{array}{c}0.131 \\
{[0.056]^{* *}}\end{array}$ & $\begin{array}{c}-0.088 \\
{[0.035]^{\star *}}\end{array}$ & $\begin{array}{l}-0.023 \\
{[0.043]}\end{array}$ \\
\hline upper secondary completed & $\begin{array}{l}-0.076 \\
{[0.052]}\end{array}$ & $\begin{array}{c}-0.185 \\
{[0.100]^{*}}\end{array}$ & $\begin{array}{l}-0.043 \\
{[0.045]}\end{array}$ & $\begin{array}{l}-0.079 \\
{[0.055]}\end{array}$ \\
\hline beyond secondary/incomplete college & $\begin{array}{c}0.035 \\
{[0.116]}\end{array}$ & $\begin{array}{c}-0.263 \\
{[0.123]^{* *}}\end{array}$ & $\begin{array}{c}0.002 \\
{[0.047]}\end{array}$ & $\begin{array}{l}-0.011 \\
{[0.051]}\end{array}$ \\
\hline university degree completed & $\begin{array}{c}-0.116 \\
{[0.057]^{\star *}}\end{array}$ & $\begin{array}{c}-0.031 \\
{[0.084]} \\
\end{array}$ & $\begin{array}{l}-0.076 \\
{[0.053]}\end{array}$ & $\begin{array}{c}0.096 \\
{[0.053]^{\star}}\end{array}$ \\
\hline Relative distance from the median earnings (above) & $\begin{array}{c}-0.109 \\
{[0.046]^{\star *}}\end{array}$ & $\begin{array}{c}-0.162 \\
{[0.095]^{*}}\end{array}$ & $\begin{array}{c}0.019 \\
{[0.044]}\end{array}$ & $\begin{array}{c}0.004 \\
{[0.067]}\end{array}$ \\
\hline Relative distance from the median earnings (below) & $\begin{array}{c}-0.388 \\
{[0.104]^{\star * *}}\end{array}$ & $\begin{array}{l}-0.105 \\
{[0.146]}\end{array}$ & $\begin{array}{c}-0.41 \\
{[0.084]^{\star * *}}\end{array}$ & $\begin{array}{c}-0.129 \\
{[0.129]}\end{array}$ \\
\hline tolerance for inequality attitude & $\begin{array}{c}0.003 \\
{[0.034]}\end{array}$ & $\begin{array}{c}0.043 \\
{[0.029]}\end{array}$ & $\begin{array}{c}-0.137 \\
{[0.039]^{\star * \star}}\end{array}$ & $\begin{array}{l}-0.017 \\
{[0.024]}\end{array}$ \\
\hline general inequality attitude & $\begin{array}{c}0.092 \\
{[0.041]^{\star *}}\end{array}$ & $\begin{array}{l}-0.018 \\
{[0.030]}\end{array}$ & $\begin{array}{c}0.007 \\
{[0.027]}\end{array}$ & $\begin{array}{c}0.021 \\
{[0.025]}\end{array}$ \\
\hline collective action inequality attitude & $\begin{array}{c}0.015 \\
{[0.031]} \\
\end{array}$ & $\begin{array}{c}0.064 \\
{[0.031]^{\star \star}}\end{array}$ & $\begin{array}{c}0.026 \\
{[0.024]}\end{array}$ & $\begin{array}{c}0.006 \\
{[0.023]}\end{array}$ \\
\hline 1992×tolerance for inequality attitude & $\begin{array}{c}-0.05 \\
{[0.041]}\end{array}$ & & $\begin{array}{c}0.092 \\
{[0.050]^{*}}\end{array}$ & \\
\hline 1999×tolerance for inequality attitude & $\begin{array}{c}0.017 \\
{[0.051]}\end{array}$ & $\begin{array}{l}-0.022 \\
{[0.058]}\end{array}$ & $\begin{array}{c}0.144 \\
{[0.046]^{\star * \star}}\end{array}$ & $\begin{array}{c}0.024 \\
{[0.045]}\end{array}$ \\
\hline $1992 \times$ general inequality attitude & $\begin{array}{l}-0.074 \\
{[0.048]}\end{array}$ & & $\begin{array}{c}0.013 \\
{[0.040]}\end{array}$ & \\
\hline $1999 \times$ general inequality attitude & $\begin{array}{c}-0.02 \\
{[0.062]}\end{array}$ & $\begin{array}{c}0.03 \\
{[0.057]}\end{array}$ & $\begin{array}{c}0.067 \\
{[0.044]}\end{array}$ & $\begin{array}{c}0.085 \\
{[0.045]^{\star}}\end{array}$ \\
\hline $1992 \times$ collective action inequality attitude & $\begin{array}{c}0.02 \\
{[0.040]}\end{array}$ & & $\begin{array}{c}0.019 \\
{[0.037]}\end{array}$ & \\
\hline $1999 \times$ collective action inequality attitude & $\begin{array}{l}-0.011 \\
{[0.050]}\end{array}$ & $\begin{array}{c}-0.145 \\
{[0.059]^{\star \star}}\end{array}$ & $\begin{array}{c}-0.078 \\
{[0.041]^{*}}\end{array}$ & $\begin{array}{l}-0.014 \\
{[0.045]}\end{array}$ \\
\hline $\begin{array}{l}\text { Observations } \\
\text { Pseudo R-squared }\end{array}$ & $\begin{array}{l}918 \\
0.1\end{array}$ & $\begin{array}{l}412 \\
0.11\end{array}$ & $\begin{array}{l}1160 \\
0.18\end{array}$ & $\begin{array}{l}755 \\
0.18\end{array}$ \\
\hline Log likelihood & -536.26 & -242.86 & -647.64 & -410.97 \\
\hline
\end{tabular}

Robust standard errors in brackets - * significant at 10\%; ** significant at 5\%; *** significant at 1\% -

Missing values are replaced with sample averages, in order not to reduce sample size 


\section{Appendix}

Table A1 - Descriptive statistics

\begin{tabular}{|c|c|c|c|c|c|c|c|c|c|c|c|c|c|}
\hline $\begin{array}{c}\text { West } \\
\text { Germany - } \\
\text { means }\end{array}$ & union & female & married & part-time & public & $\begin{array}{l}\text { completed } \\
\text { secondary }\end{array}$ & $\begin{array}{l}\text { uncompl } \\
\text { college }\end{array}$ & college & $\begin{array}{l}\text { supervis. } \\
\text { someone }\end{array}$ & age & $\begin{array}{c}\text { years of } \\
\text { schooling }\end{array}$ & $\begin{array}{c}\text { working } \\
\text { hours }\end{array}$ & $\begin{array}{l}\text { sample } \\
\text { size }\end{array}$ \\
\hline 1985 & 0.353 & 0.380 & 0.662 & 0.143 & 0.311 & 0.013 & 0.034 & 0.138 & & 39.434 & 10.420 & 42.139 & 464 \\
\hline 1986 & 0.301 & 0.375 & 0.625 & 0.146 & 0.213 & 0.084 & 0.065 & 0.088 & & 37.578 & 10.398 & 40.299 & 1.196 \\
\hline 1987 & 0.376 & 0.384 & 0.642 & 0.140 & 0.315 & 0.063 & 0.033 & 0.079 & 0.322 & 39.689 & 10.315 & 39.806 & 490 \\
\hline 1988 & 0.271 & 0.424 & 0.588 & 0.166 & 0.203 & 0.099 & 0.020 & 0.091 & & 37.360 & & 39.131 & 1.234 \\
\hline 1989 & 0.344 & 0.429 & 0.603 & 0.190 & 0.262 & 0.093 & 0.016 & 0.074 & 0.255 & 38.072 & 10.149 & 38.822 & 578 \\
\hline 1990 & 0.318 & 0.387 & 0.580 & 0.129 & 0.321 & 0.104 & 0.032 & 0.114 & 0.425 & 38.419 & 10.645 & 39.078 & 1.196 \\
\hline 1991 & 0.291 & 0.395 & 0.635 & 0.183 & 0.312 & 0.073 & 0.080 & 0.095 & 0.457 & 38.714 & 10.827 & 38.993 & 612 \\
\hline 1992 & 0.352 & 0.405 & 0.611 & 0.169 & 0.311 & 0.094 & 0.063 & 0.129 & 0.429 & 38.049 & 10.507 & 38.159 & 969 \\
\hline 1993 & 0.386 & 0.402 & 0.625 & 0.168 & 0.269 & 0.075 & 0.061 & 0.086 & & 38.780 & 10.556 & 37.231 & 425 \\
\hline 1994 & 0.246 & 0.368 & 0.604 & 0.134 & 0.266 & 0.059 & 0.067 & 0.099 & 0.422 & 37.947 & & & 1.035 \\
\hline 1995 & 0.276 & 0.380 & 0.663 & 0.187 & 0.361 & 0.138 & 0.067 & 0.108 & 0.533 & 40.330 & 11.457 & 38.584 & 631 \\
\hline 1996 & 0.267 & 0.387 & 0.624 & 0.128 & 0.273 & 0.066 & 0.045 & 0.078 & 0.453 & 38.566 & 9.844 & & 589 \\
\hline 1997 & 0.261 & 0.399 & 0.590 & 0.131 & 0.346 & 0.078 & 0.076 & 0.123 & 0.452 & 40.447 & 11.795 & 38.637 & 602 \\
\hline 1998 & 0.260 & 0.394 & 0.544 & 0.090 & 0.251 & 0.045 & 0.087 & 0.107 & 0.397 & 39.538 & 11.020 & 38.930 & 354 \\
\hline 1999 & 0.236 & 0.392 & 0.593 & 0.139 & 0.284 & 0.129 & & 0.095 & 0.456 & 40.336 & 10.607 & 39.737 & 423 \\
\hline 2000 & 0.230 & 0.435 & 0.626 & 0.161 & 0.308 & 0.084 & 0.002 & 0.120 & 0.460 & 40.966 & 10.741 & 38.959 & 439 \\
\hline 2001 & 0.258 & 0.403 & 0.551 & 0.120 & 0.308 & 0.084 & 0.072 & 0.128 & 0.515 & 39.877 & 11.449 & 39.823 & 431 \\
\hline 2002 & 0.197 & 0.433 & 0.562 & 0.155 & 0.262 & 0.087 & 0.085 & 0.153 & 0.512 & 39.775 & 11.613 & 39.618 & 426 \\
\hline Total & 0.292 & 0.396 & 0.608 & 0.149 & 0.281 & 0.084 & 0.049 & 0.103 & 0.434 & 38.750 & 10.682 & 39.223 & 12.094 \\
\hline
\end{tabular}

East

\begin{tabular}{|c|c|c|c|c|c|c|c|c|c|c|c|c|c|}
\hline $\begin{array}{c}\text { East } \\
\text { Germany - } \\
\text { means }\end{array}$ & union & female & married & part-time & public & $\begin{array}{l}\text { completed } \\
\text { secondary }\end{array}$ & $\begin{array}{l}\text { uncompl } \\
\text { college }\end{array}$ & college & $\begin{array}{l}\text { supervis. } \\
\text { someone }\end{array}$ & age & $\begin{array}{c}\text { years of } \\
\text { schooling }\end{array}$ & $\begin{array}{c}\text { working } \\
\text { hours }\end{array}$ & $\begin{array}{c}\text { sample } \\
\text { size }\end{array}$ \\
\hline 1991 & 0.501 & 0.496 & 0.734 & 0.239 & 0.350 & 0.068 & & 0.123 & 0.332 & 39.018 & 10.600 & 41.674 & 815 \\
\hline 1992 & 0.476 & 0.497 & 0.709 & 0.119 & 0.361 & 0.048 & 0.040 & 0.148 & 0.309 & 38.421 & 10.702 & 41.809 & 519 \\
\hline 1993 & 0.455 & 0.468 & 0.649 & 0.072 & 0.315 & 0.029 & 0.117 & 0.107 & & 38.952 & 10.596 & 41.073 & 411 \\
\hline 1994 & 0.394 & 0.438 & 0.712 & 0.101 & 0.303 & 0.041 & 0.075 & 0.120 & 0.322 & 38.998 & & & 416 \\
\hline 1995 & 0.332 & 0.449 & 0.726 & 0.147 & 0.393 & 0.093 & 0.100 & 0.156 & 0.444 & 41.151 & 11.547 & 41.227 & 271 \\
\hline 1996 & 0.304 & 0.441 & 0.690 & 0.087 & 0.265 & 0.079 & 0.038 & 0.079 & 0.358 & 39.893 & 9.833 & & 247 \\
\hline 1997 & 0.272 & 0.453 & 0.720 & 0.053 & 0.354 & 0.049 & 0.160 & 0.177 & 0.407 & 41.535 & 13.022 & 42.858 & 243 \\
\hline 1998 & 0.169 & 0.466 & 0.575 & 0.118 & 0.277 & 0.035 & 0.153 & 0.074 & 0.266 & 38.410 & 10.994 & 40.490 & 338 \\
\hline 1999 & 0.210 & 0.476 & 0.675 & 0.104 & 0.277 & 0.095 & 0.004 & 0.104 & 0.320 & 40.749 & 11.476 & 41.330 & 229 \\
\hline 2000 & 0.156 & 0.482 & 0.584 & 0.106 & 0.243 & 0.071 & & 0.124 & 0.332 & 40.000 & 11.637 & 41.380 & 225 \\
\hline 2001 & 0.222 & 0.466 & 0.583 & 0.034 & 0.299 & 0.074 & 0.049 & 0.138 & 0.397 & 39.547 & 12.015 & 43.377 & 203 \\
\hline 2002 & 0.181 & 0.438 & 0.624 & 0.096 & 0.315 & 0.045 & 0.073 & 0.180 & 0.441 & 40.803 & 12.326 & 41.865 & 177 \\
\hline Total & 0.355 & 0.468 & 0.680 & 0.123 & 0.318 & 0.060 & 0.060 & 0.122 & 0.346 & 39.504 & 11.021 & 41.621 & 4.094 \\
\hline
\end{tabular}

\begin{tabular}{|c|c|c|c|c|c|c|c|c|c|c|c|c|c|}
\hline $\begin{array}{l}\text { Sweden - } \\
\text { means }\end{array}$ & union & female & married & part-time & public & $\begin{array}{l}\text { completed } \\
\text { secondary }\end{array}$ & $\begin{array}{l}\text { uncompl } \\
\text { college }\end{array}$ & college & $\begin{array}{l}\text { supervis. } \\
\text { someone }\end{array}$ & age & $\begin{array}{l}\text { years of } \\
\text { schooling }\end{array}$ & $\begin{array}{l}\text { working } \\
\text { hours }\end{array}$ & $\begin{array}{l}\text { sample } \\
\text { size }\end{array}$ \\
\hline 1994 & 0.830 & 0.509 & 0.766 & 0.258 & 0.503 & 0.177 & 0.053 & 0.210 & 0.360 & 42.630 & 11.927 & 37.597 & 752 \\
\hline 1995 & 0.870 & 0.523 & 0.723 & 0.249 & 0.531 & 0.152 & 0.069 & 0.256 & 0.350 & 41.807 & 11.986 & 37.718 & 682 \\
\hline 1996 & 0.882 & 0.512 & 0.735 & 0.250 & 0.525 & 0.163 & 0.071 & 0.242 & 0.345 & 42.839 & 11.974 & 37.547 & 642 \\
\hline 1997 & 0.872 & 0.516 & 0.532 & 0.241 & 0.506 & 0.040 & 0.075 & 0.255 & 0.302 & 43.288 & 12.338 & 37.821 & 711 \\
\hline 1998 & 0.845 & 0.537 & 0.743 & 0.248 & 0.536 & 0.165 & 0.073 & 0.261 & 0.338 & 41.476 & 12.533 & 38.390 & 613 \\
\hline 1999 & 0.834 & 0.521 & 0.488 & 0.229 & 0.498 & 0.223 & 0.065 & 0.216 & 0.312 & 41.744 & 12.174 & 38.533 & 634 \\
\hline 2000 & 0.827 & 0.503 & 0.510 & 0.192 & 0.493 & 0.159 & 0.098 & 0.268 & 0.316 & 42.997 & 12.740 & 38.757 & 568 \\
\hline 2002 & 0.841 & 0.528 & 0.506 & 0.238 & 0.536 & 0.173 & 0.067 & 0.329 & 0.355 & 43.929 & 12.756 & 37.825 & 592 \\
\hline Total & 0.851 & 0.519 & 0.630 & 0.239 & 0.516 & 0.155 & 0.071 & 0.253 & 0.335 & 42.584 & 12.282 & 37.990 & 5.194 \\
\hline $\begin{array}{l}\text { Norway - } \\
\text { means }\end{array}$ & union & female & married & part-time & public & $\begin{array}{l}\text { completed } \\
\text { secondary }\end{array}$ & $\begin{array}{l}\text { uncompl } \\
\text { college }\end{array}$ & college & $\begin{array}{l}\text { supervis. } \\
\text { someone }\end{array}$ & age & $\begin{array}{l}\text { years of } \\
\text { schooling }\end{array}$ & $\begin{array}{c}\text { working } \\
\text { hours }\end{array}$ & $\begin{array}{l}\text { sample } \\
\text { size }\end{array}$ \\
\hline 1989 & 0.567 & 0.485 & 0.713 & 0.272 & 0.376 & 0.278 & & 0.313 & 0.335 & 38.886 & 10.586 & 32.079 & 1.119 \\
\hline 1990 & 0.638 & 0.436 & 0.763 & 0.141 & 0.499 & 0.132 & 0.224 & 0.082 & 0.443 & 39.234 & 11.563 & 38.213 & 779 \\
\hline 1991 & 0.652 & 0.466 & 0.793 & 0.129 & 0.520 & 0.170 & 0.190 & 0.138 & 0.443 & 38.513 & 12.438 & 38.363 & 710 \\
\hline 1992 & 0.625 & 0.499 & 0.789 & 0.121 & 0.518 & 0.149 & 0.187 & 0.160 & 0.430 & 39.262 & 12.628 & 38.531 & 747 \\
\hline 1993 & 0.649 & 0.455 & 0.789 & 0.165 & 0.481 & 0.353 & 0.306 & 0.208 & 0.459 & 39.679 & 12.772 & 39.508 & 767 \\
\hline 1994 & 0.617 & 0.492 & 0.630 & 0.192 & 0.456 & 0.483 & 0.152 & 0.199 & 0.438 & 39.539 & 13.383 & 38.946 & 1.092 \\
\hline 1995 & 0.673 & 0.471 & 0.596 & 0.124 & 0.489 & 0.313 & 0.105 & 0.263 & 0.499 & 39.258 & 13.479 & 37.862 & 676 \\
\hline 1996 & 0.630 & 0.456 & 0.590 & 0.108 & 0.439 & 0.287 & 0.101 & 0.276 & 0.506 & 40.173 & 13.731 & 39.032 & 668 \\
\hline 1997 & 0.587 & 0.486 & 0.564 & 0.140 & 0.483 & 0.293 & 0.111 & 0.277 & 0.302 & 39.828 & 12.874 & 38.373 & 1.24 \\
\hline 1998 & 0.646 & 0.513 & 0.582 & 0.127 & 0.473 & 0.326 & 0.093 & 0.325 & 0.356 & 39.746 & 13.751 & 38.600 & 825 \\
\hline 1999 & 0.653 & 0.496 & 0.560 & 0.105 & 0.513 & 0.332 & 0.126 & 0.351 & 0.361 & 40.281 & 13.308 & 38.859 & 631 \\
\hline 2000 & 0.612 & 0.436 & 0.557 & 0.101 & 0.497 & 0.354 & 0.117 & 0.331 & 0.319 & 41.259 & 13.953 & 38.433 & 735 \\
\hline 2001 & 0.633 & 0.502 & 0.596 & 0.125 & 0.520 & 0.371 & 0.120 & 0.299 & 0.342 & 41.647 & 13.668 & 38.393 & 815 \\
\hline 2002 & 0.610 & 0.498 & 0.594 & 0.129 & 0.421 & 0.330 & 0.132 & 0.348 & 0.353 & 42.072 & 13.846 & 39.012 & 811 \\
\hline Total & 0.624 & 0.479 & 0.649 & 0.148 & 0.473 & 0.304 & 0.150 & 0.256 & 0.393 & 39.920 & 12.931 & 37.996 & 11.615 \\
\hline
\end{tabular}




\begin{tabular}{|c|c|c|c|c|c|c|c|c|c|c|c|c|c|}
\hline $\begin{array}{l}\text { Italy - } \\
\text { means }\end{array}$ & union & female & married & part-time & public & $\begin{array}{l}\text { completed } \\
\text { secondary }\end{array}$ & $\begin{array}{l}\text { uncompl } \\
\text { college }\end{array}$ & college & $\begin{array}{l}\text { supervis. } \\
\text { someone }\end{array}$ & age & $\begin{array}{l}\text { years of } \\
\text { schooling }\end{array}$ & $\begin{array}{c}\text { working } \\
\text { hours }\end{array}$ & $\begin{array}{c}\text { sample } \\
\text { size }\end{array}$ \\
\hline 1985 & 0.378 & 0.325 & 0.691 & & & 0.347 & 0.077 & 0.122 & & 39.873 & 11.085 & & 753 \\
\hline 1986 & 0.408 & 0.344 & 0.701 & 0.263 & 0.506 & 0.383 & 0.042 & 0.117 & & 30.466 & 10.885 & 35.503 & 358 \\
\hline 1988 & 0.391 & 0.408 & 0.653 & 0.249 & 0.565 & 0.479 & & 0.154 & & 38.191 & 12.034 & 38.430 & 407 \\
\hline 1990 & 0.440 & 0.431 & 0.649 & 0.095 & 0.569 & 0.466 & & 0.180 & 0.283 & 38.975 & 12.530 & 36.003 & 357 \\
\hline 1991 & 0.440 & 0.431 & 0.649 & 0.095 & 0.569 & 0.466 & & 0.180 & 0.283 & 38.975 & 12.530 & 36.003 & 357 \\
\hline 1992 & 0.422 & 0.365 & 0.635 & 0.154 & 0.415 & 0.360 & 0.052 & 0.099 & 0.253 & 37.022 & 11.734 & 36.676 & 344 \\
\hline 1993 & 0.425 & 0.368 & 0.653 & 0.163 & 0.409 & 0.264 & 0.446 & 0.106 & 0.280 & 39.446 & 11.096 & 37.702 & 362 \\
\hline 1994 & 0.356 & 0.366 & 0.663 & 0.181 & 0.426 & 0.369 & 0.050 & 0.092 & 0.288 & 38.894 & 11.463 & 37.587 & 362 \\
\hline 1995 & 0.340 & 0.369 & 0.676 & 0.231 & 0.283 & 0.396 & 0.070 & 0.114 & 0.274 & 39.173 & 12.106 & 39.378 & 374 \\
\hline 1996 & 0.330 & 0.398 & 0.663 & 0.262 & 0.387 & 0.395 & 0.064 & 0.113 & 0.234 & 38.078 & 11.826 & 36.497 & 309 \\
\hline 1997 & 0.312 & 0.348 & 0.643 & 0.123 & 0.387 & 0.375 & 0.069 & 0.099 & 0.339 & 37.970 & 11.673 & 37.945 & 333 \\
\hline 1998 & 0.362 & 0.408 & 0.627 & 0.142 & 0.399 & 0.364 & 0.085 & 0.130 & 0.242 & 37.845 & 12.173 & 36.652 & 312 \\
\hline Total & 0.384 & 0.376 & 0.662 & 0.181 & 0.442 & 0.386 & 0.104 & 0.125 & 0.276 & 38.139 & 11.715 & 37.254 & 4.628 \\
\hline $\begin{array}{c}\text { Netherlands } \\
\text { - means }\end{array}$ & union & female & married & part-time & public & $\begin{array}{l}\text { completed } \\
\text { secondary }\end{array}$ & $\begin{array}{c}\text { uncompl } \\
\text { college }\end{array}$ & college & $\begin{array}{l}\text { supervis. } \\
\text { someone }\end{array}$ & age & $\begin{array}{c}\text { years of } \\
\text { schooling }\end{array}$ & $\begin{array}{c}\text { working } \\
\text { hours }\end{array}$ & $\begin{array}{c}\text { sample } \\
\text { size }\end{array}$ \\
\hline 1987 & 0.309 & 0.348 & 0.657 & 0.238 & 0.343 & 0.096 & 0.196 & 0.100 & 0.391 & 36.457 & 13.103 & 35.109 & 601 \\
\hline 1988 & 0.318 & 0.359 & 0.635 & 0.233 & 0.309 & 0.110 & 0.137 & 0.123 & 0.341 & 35.501 & 13.188 & 37.076 & 617 \\
\hline 1989 & 0.307 & 0.343 & 0.583 & 0.249 & 0.296 & 0.093 & 0.126 & 0.103 & 0.317 & 35.146 & 12.669 & 36.326 & 615 \\
\hline 1991 & 0.305 & 0.393 & 0.620 & 0.280 & 0.235 & 0.096 & 0.173 & 0.161 & 0.337 & 36.334 & 13.828 & 35.848 & 603 \\
\hline 1993 & 0.349 & 0.400 & 0.658 & 0.304 & 0.302 & 0.377 & 0.174 & 0.121 & 0.301 & 37.851 & 13.612 & 35.704 & 599 \\
\hline 1994 & 0.349 & 0.400 & 0.590 & 0.288 & 0.231 & 0.118 & 0.138 & 0.178 & 0.333 & 37.569 & 13.772 & 35.859 & 682 \\
\hline 1995 & 0.356 & 0.395 & 0.620 & 0.354 & 0.270 & 0.371 & 0.100 & 0.212 & 0.282 & 37.854 & 14.305 & 34.341 & 765 \\
\hline 1997 & 0.341 & 0.456 & 0.606 & 0.411 & 0.252 & 0.141 & 0.009 & 0.204 & 0.268 & 38.566 & 13.709 & 32.550 & 1.012 \\
\hline 1998 & 0.314 & 0.454 & 0.622 & 0.377 & 0.213 & 0.515 & & 0.238 & 0.315 & 38.665 & 13.986 & 33.445 & 972 \\
\hline 2000 & 0.352 & 0.420 & 0.600 & 0.364 & 0.172 & 0.476 & & 0.223 & 0.294 & 38.742 & 13.592 & 33.316 & 793 \\
\hline 2002 & 0.304 & 0.453 & 0.586 & 0.393 & 0.225 & 0.433 & & 0.414 & 0.307 & 40.541 & 14.220 & 33.205 & 642 \\
\hline Total & 0.329 & 0.407 & 0.615 & 0.327 & 0.254 & 0.271 & 0.084 & 0.195 & 0.312 & 37.715 & 13.672 & 34.566 & 7.901 \\
\hline $\begin{array}{c}\text { Britain - } \\
\text { means }\end{array}$ & union & female & married & part-time & public & $\begin{array}{l}\text { completed } \\
\text { secondary }\end{array}$ & $\begin{array}{c}\text { uncompl } \\
\text { college }\end{array}$ & college & $\begin{array}{l}\text { supervis. } \\
\text { someone }\end{array}$ & age & $\begin{array}{c}\text { years of } \\
\text { schooling }\end{array}$ & $\begin{array}{c}\text { working } \\
\text { hours }\end{array}$ & $\begin{array}{c}\text { sample } \\
\text { size }\end{array}$ \\
\hline 1985 & 0.473 & 0.457 & 0.713 & 0.292 & 0.356 & 0.106 & 0.159 & 0.097 & 0.370 & 38.124 & 11.227 & 37.525 & 725 \\
\hline 1986 & 0.478 & 0.420 & 0.768 & 0.288 & 0.359 & 0.118 & 0.159 & 0.082 & 0.383 & 39.293 & 11.158 & 37.282 & 696 \\
\hline 1987 & 0.457 & 0.489 & 0.724 & 0.313 & 0.382 & 0.097 & 0.166 & 0.111 & 0.406 & 39.294 & 11.379 & 36.831 & 597 \\
\hline 1988 & 0.464 & 0.486 & 0.706 & 0.000 & 0.393 & 0.133 & 0.168 & 0.120 & 0.395 & 38.165 & 11.454 & 38.328 & 619 \\
\hline 1989 & 0.429 & 0.470 & 0.747 & 0.198 & 0.334 & 0.115 & 0.189 & 0.080 & 0.424 & 39.663 & 11.263 & 37.941 & 625 \\
\hline 1990 & 0.398 & 0.528 & 0.737 & 0.219 & 0.357 & 0.108 & 0.187 & 0.110 & 0.384 & 38.901 & 11.377 & 36.725 & 565 \\
\hline 1991 & 0.648 & 0.515 & 0.615 & 0.198 & 0.381 & 0.126 & 0.219 & 0.130 & 0.385 & 38.419 & 11.627 & 37.032 & 469 \\
\hline 1992 & 0.429 & 0.518 & 0.705 & 0.168 & 0.376 & 0.361 & 0.198 & 0.138 & 0.378 & 40.228 & 11.617 & 37.359 & 464 \\
\hline 1993 & 0.383 & 0.493 & 0.709 & 0.296 & 0.302 & 0.196 & 0.308 & 0.105 & 0.413 & 38.789 & 11.497 & 35.351 & 496 \\
\hline 1994 & 0.435 & 0.530 & 0.668 & 0.234 & & 0.409 & 0.083 & 0.145 & 0.408 & 39.212 & 11.711 & 37.107 & 448 \\
\hline 1995 & 0.368 & 0.570 & 0.675 & 0.206 & & 0.405 & 0.208 & 0.137 & 0.404 & 38.435 & 11.658 & 38.021 & 437 \\
\hline 1996 & 0.350 & 0.542 & 0.673 & 0.213 & 0.307 & 0.129 & 0.206 & 0.186 & 0.389 & 38.834 & 12.299 & 38.451 & 403 \\
\hline 1997 & 0.353 & 0.560 & 0.640 & 0.219 & 0.323 & 0.128 & 0.194 & 0.183 & 0.349 & 39.100 & 12.430 & 38.296 & 470 \\
\hline 1998 & 0.336 & 0.567 & 0.674 & 0.279 & 0.321 & 0.121 & 0.251 & 0.110 & 0.354 & 40.219 & 12.176 & 37.688 & 390 \\
\hline 1999 & 0.325 & 0.486 & 0.658 & 0.244 & 0.275 & 0.148 & 0.178 & 0.150 & 0.333 & 40.064 & 12.186 & 36.458 & 360 \\
\hline 2000 & 0.311 & 0.552 & 0.640 & 0.285 & 0.287 & 0.124 & 0.162 & 0.190 & 0.382 & 39.340 & 12.499 & 39.059 & 453 \\
\hline 2001 & 0.344 & 0.572 & 0.594 & 0.258 & 0.333 & 0.163 & 0.170 & 0.204 & 0.350 & 39.630 & 12.533 & 36.734 & 410 \\
\hline 2002 & 0.324 & 0.540 & 0.612 & 0.240 & 0.328 & 0.180 & 0.164 & 0.216 & 0.387 & 40.279 & 12.625 & 38.564 & 956 \\
\hline Total & 0.410 & 0.511 & 0.684 & 0.231 & 0.342 & 0.169 & 0.184 & 0.137 & 0.385 & 39.218 & 11.784 & 37.537 & 9.583 \\
\hline
\end{tabular}


Table A2 - Probit regression of union membership (marginal effects) - ISSP 1985-2002 Instrumental Variables

\begin{tabular}{|c|c|c|c|c|c|c|c|}
\hline & $\begin{array}{c}\text { West } \\
\text { Germany }\end{array}$ & $\begin{array}{c}\text { East } \\
\text { Germany }\end{array}$ & Sweden & Norway & Italy & Netherlands & Britain \\
\hline \multirow[t]{2}{*}{ Female } & -0.119 & -0.019 & 0 & 0.031 & -0.126 & -0.047 & -0.054 \\
\hline & {$[0.023]^{\star \star \star}$} & {$[0.031]$} & {$[0.013]$} & {$[0.019]$} & {$[0.020]^{\star \star \star}$} & {$[0.020]^{\star *}$} & {$[0.017]^{\star \star \star}$} \\
\hline \multirow[t]{2}{*}{ Young } & -0.028 & -0.049 & -0.133 & -0.088 & -0.18 & -0.115 & -0.11 \\
\hline & {$[0.028]$} & {$[0.049]$} & {$[0.028]^{\star \star \star}$} & {$[0.023]^{\star \star \star}$} & {$[0.027]^{\star \star \star}$} & {$[0.021]^{\star \star \star}$} & {$[0.014]^{\star \star *}$} \\
\hline \multirow[t]{2}{*}{ Married } & 0.039 & -0.017 & 0.028 & 0.047 & 0.081 & -0.103 & 0.042 \\
\hline & {$[0.014]^{\star \star *}$} & {$[0.026]$} & {$[0.012]^{\star \star}$} & {$[0.012]^{\star \star \star}$} & {$[0.023]^{\star \star \star}$} & {$[0.044]^{\star *}$} & {$[0.013]^{\star \star \star}$} \\
\hline \multirow[t]{2}{*}{ working less than fulltime } & -0.003 & 0.138 & -0.028 & 0.097 & -0.15 & 0.044 & 0.133 \\
\hline & {$[0.061]$} & {$[0.089]$} & {$[0.046]$} & {$[0.044]^{\star \star}$} & {$[0.040]^{\star \star \star}$} & {$[0.035]$} & {$[0.052]^{\star \star}$} \\
\hline \multirow[t]{2}{*}{ working for government/public owned } & 0.109 & 0.066 & 0.125 & 0.374 & 0.192 & 0.124 & 0.375 \\
\hline & {$[0.017]^{\star \star \star}$} & {$[0.033]^{\star \star}$} & {$[0.012]^{\star \star \star}$} & {$[0.011]^{\star \star \star}$} & {$[0.039]^{\star \star \star}$} & {$[0.022]^{\star \star \star}$} & {$[0.015]^{\star \star \star}$} \\
\hline \multirow[t]{2}{*}{ Supervising someone } & -0.025 & 0.015 & -0.035 & -0.042 & 0.112 & 0.009 & -0.037 \\
\hline & {$[0.019]$} & {$[0.030]$} & {$[0.014]^{\star *}$} & {$[0.017]^{\star \star}$} & {$[0.031]^{\star \star \star}$} & {$[0.019]$} & {$[0.016]^{\star \star}$} \\
\hline \multirow[t]{2}{*}{ Relative distance from the median earnings (above) } & -0.368 & -0.331 & -0.157 & -0.305 & -0.327 & -0.583 & -0.337 \\
\hline & {$[0.045]^{\star \star *}$} & {$[0.126]^{\star \star \star}$} & {$[0.045]^{\star \star \star}$} & {$[0.070]^{\star \star \star}$} & {$[0.197]^{\star}$} & {$[0.156]^{\star \star \star}$} & {$[0.055]^{\star \star \star}$} \\
\hline \multirow[t]{2}{*}{ Relative distance from the median earnings (below) } & -0.797 & -0.688 & -0.089 & -1.123 & 0.143 & -1.817 & -1.041 \\
\hline & {$[0.242]^{\star \star \star}$} & {$[0.461]$} & {$[0.187]$} & {$[0.194]^{\star \star \star}$} & {$[0.409]$} & {$[0.582]^{\star \star \star}$} & {$[0.161]^{\star \star \star}$} \\
\hline Observations & 8842 & 3141 & 4902 & 10954 & 4078 & 7066 & 9269 \\
\hline Pseudo R-squared & 0.07 & 0.08 & 0.09 & 0.16 & 0.08 & 0.05 & 0.14 \\
\hline Log likelihood & -5016.68 & -1890.34 & -1808.42 & -6035.92 & -2524.87 & -4298.12 & -5393 \\
\hline
\end{tabular}

Standard errors in brackets - * significant at 10\%; ** significant at 5\%; ** significant at 1\% - Year dummies included -

Endogenous: above and below the median - Instrumental Variables: secondary-uncompleted college-college-collegexfemale 